\title{
Local Dividend Clienteles
}

\section{BO BECKER, ZORAN IVKOVIĆ, and SCOTT WEISBENNER*}

\begin{abstract}
We exploit demographic variation to identify the effect of dividend demand on corporate payout policy. Retail investors tend to hold local stocks and older investors prefer dividend-paying stocks. Together, these tendencies generate geographically varying demand for dividends. Firms headquartered in areas in which seniors constitute a large fraction of the population are more likely to pay dividends, initiate dividends, and have higher dividend yields. We also provide indirect evidence as to why managers may respond to the demand for dividends from local seniors. Overall, these results are consistent with the notion that the investor base affects corporate policy choices.
\end{abstract}

* Becker is at Harvard Business School; Ivković is at Michigan State University; and Weisbenner is at the University of Illinois at Urbana-Champaign and the NBER. We thank Heitor Almeida, Vidhan Goyal, Denis Gromb, Christian Leuz, Andrew Metrick, Joshua Pollet, Raghu Rajan, Xuan Tian, Michael Weisbach, Joshua White, seminar participants at the Chinese University of Hong Kong, City University of Hong Kong, Emory University, Harvard Business School, London Business School, McGill University, Massey University, Nanyang Technological University, Singapore Management University, Temple University, University of Hong Kong, University of Illinois at Urbana-Champaign, University of Toronto, Victoria University of Wellington, Yale University, as well as participants at NBER Corporate Finance Meeting (March 2007), American Finance Association Meetings (January 2008), FIRS Finance Conference (June 2008), and Florida State University Beach Conference (April 2009) for comments and suggestions. We also thank the Editor (Campbell Harvey), Co-Editor (John Graham), and two anonymous referees for their comments and suggestions. The views expressed herein are those of the authors and not necessarily those of the National Bureau of Economic Research. An Internet Appendix containing supporting material is available at http://www.afajof.org/supplements.asp. 
This paper examines the role of investor demand in shaping corporate payout policy. Miller and Modigliani (1961) suggest that matching takes place between investor clienteles who demand dividends and those firms that find it less costly to pay them, that is, companies set payout policy and investors sort based on their preferences for dividends. On the other hand, firms may actively respond to the preferences of their current shareholders. The empirical patterns will be the same regardless of the direction of the underlying causal relation (payout policies match investor preferences), but the implications for understanding corporate policy are very different. For example, if companies adjust policy in response to the composition of their current investors, then it clearly matters who the shareholders actually are.

We test whether shareholder demand for dividends influences firm payout policy. The challenge is to quantify dividend demand, that is, to find a variable that reflects investor demand for dividends, but does not also proxy for dividend supply from firms (firms might be more likely to pay or supply dividends because of a lack of investment opportunities).

We seek to identify the effect of dividend demand on firm policy by exploiting geographical variation in the population of retail investors. Our identification strategy is based upon two notions. First, seniors have a preference for dividend-paying stocks. ${ }^{1}$ Several reasons have been proposed for this preference. Miller and Modigliani (1961) and Shefrin and Thaler (1988), among others, stress the role of life-cycle considerations-older investors may prefer dividend-paying stocks for consumption purposes. Thaler and Shefrin (1981) further point to self-control and regret avoidance motivations (consume from dividends and thus avoid the temptation to liquidate shares), while Shefrin and Statman (1984) stress mental accounting (dividends and capital gains are in two separate "mental accounts" and are thus potentially viewed and treated differently), and Scholz (1992) highlights a tax rationale. Because older investors likely have more pronounced needs to "cash out" larger portions of their portfolios for consumption and also likely have lower tax rates on dividends relative to younger investors, all of these motivations suggest greater demand for dividends from senior 
investors. In this paper, we do not address the reasons for seniors' preference for dividends; rather, we build upon the strong empirical evidence, provided in Graham and Kumar (2006), of the existence of an age-based dividend clientele among retail investors. The substantial demographic variation in population age structure across the U.S. (see, for example, Becker (2007)) thus lays a foundation for an identification strategy.

Second, household stock ownership tends to be local. The tendency of individual investors to hold stocks of local companies in the U.S. has been reported by Huberman (2001) and Ivković and Weisbenner (2005); it has been documented in other countries as well (e.g., Grinblatt and Keloharju (2001), and Massa and Simonov (2006)). Variation in local age structure, therefore, induces differential dividend preferences across locations. In particular, companies located in areas with more seniors will face higher demand for dividends. This implies that we can identify a component of the dividend demand facing individual firms. Our proxy for this demand is the variable Local Seniors, defined henceforth as the fraction of residents who are 65 years old or older in the county in which a company is headquartered. We use Local Seniors to test whether geographically varying dividend demand is a determinant of payout policy for U.S. corporations, thereby building upon the Miller and Modigliani (1961) framework. ${ }^{2}$

Our dividend demand hypothesis requires that a couple of conditions be satisfied. First, there must be a sorting friction such as geographically segmented markets. This assumption seems less appropriate for well-known members of the S\&P 500 index such as Microsoft or IBM. However, research suggests that location matters for many firms in terms of their access to financing (Becker (2007)), their market valuation (Hong, Kubik, and Stein (2008)), the correlation pattern in their stock returns (Pirinsky and Wang (2006)), their liquidity (Loughran and Shultz (2005)), and the composition of their shareholders (Ivković and Weisbenner (2005)). Second, management must perceive some benefit to responding to the dividend demand from local seniors or some cost in not doing so. As we discuss below, we provide suggestive evidence for this in the paper. 
Our identification strategy follows a three-tiered approach. First, we establish the underlying correlation between a firm's dividend policy and the fraction of seniors in the firm's local community. Second, we conduct a wide range of robustness tests that, in their totality, enable us to better ascertain whether companies pay dividends in response to demand from their shareholders (who are more likely to be local seniors in the areas in which the fraction of seniors is relatively high) or whether the presence of local seniors proxies for the companies' poor investment opportunities that compel them to pay dividends (the dividend supply alternative explanation). We also employ specifications that require a substantially higher hurdle to identify this "local seniors effect;" for example, we examine how dividend policy adapts to a change in the local environment (when the fraction of seniors in the county changes or when the company moves its headquarters). Finally, we provide indirect evidence as to why managers may care about adjusting dividend policy to match the demand generated by local seniors.

In the first tier of our identification strategy (identifying the underlying correlation), we show that companies headquartered in counties with a large fraction of seniors are more likely to pay dividends, initiate dividends, and pay a higher dividend yield. Increasing the proportion of seniors in a county by one standard deviation (or by 3.1 percentage points) increases the probability that a local firm is a dividend payer by approximately 1.8 percentage points, increases the probability that the firm will initiate dividends over the next year by approximately 1.0 percentage points, and increases the dividend yield by approximately $0.23 \%$ of market value. These results are obtained after controlling for firm-specific characteristics, as well as state-year and industry-year fixed effects in payout policy. Accordingly, any variable that varies only by state and year is absorbed in the state-year fixed effects and cannot explain any of our regression findings. The same holds for any variable that varies only by industry and year. Simply put, our results are not obtained by comparing firms, for example, in Florida (the state with the largest fraction of seniors) with those in Alaska (the state with the smallest fraction of seniors). Rather, they are identified by differences in the proportion of seniors across counties within a state in a given year. 
The effect of Local Seniors on dividend initiations is particularly strong given the dividend initiation rate is roughly $2 \%$ per year over our sample: a one-standard deviation increase in Local Seniors increases the likelihood of a dividend initiation by $50 \%$ of the baseline effect. To put this into perspective, a one-standard deviation increase in the fraction of seniors in a company's community has the same effect on the likelihood of dividend initiation as does a one-standard deviation increase in the firm's market capitalization, or the years since the firm was publicly listed increasing from 610 years to 16-20 years. Determinants of the dividend initiation decision are particularly relevant because, given the general "stickiness" of dividends (Lintner (1956) and Brav et al. (2005)), the decision to initiate dividends, practically speaking, really is a decision to commit to a long stream of cash outlays (as opposed to a simple one-year commitment that can be easily reversed).

A natural concern with these results and the associated dividend demand interpretation is that an omitted variable might be the true driver of dividend policy. If such a variable were correlated with the presence of seniors in communities, our results would be spurious. For example, an alternative, dividend supply theory suggests that Local Seniors might proxy for areas with low growth prospects, in which case it would characterize areas in which companies are paying dividends because they face limited future economic prospects.

Whereas it is difficult to rule out completely that such an alternative explanation could play some role in explaining our results, in the second tier of our identification strategy we provide evidence that helps differentiate our demand-based explanation from the supply-based alternative theory and thus guides us in interpreting the correlation between dividend policy and Local Seniors. We conduct a number of additional tests and alternative specifications. Some of these additional analyses simply add additional control variables to the baseline model. Others seek to identify subsets of companies for which the correlation between dividend policy and Local Seniors should be stronger (or weaker, or absent) under the dividend-demand hypothesis, whereas the supply-based alternative predicts no variation in the effect of Local Seniors. In addition 
to these robustness checks, we also employ different specifications that substantially raise the hurdle of finding any effect of Local Seniors on payout policy. Specifically, we examine how dividend policy adapts to a change in the local environment, either through the fraction of seniors in a given community changing over time or through the presence of local seniors changing because the company moved its corporate headquarters.

Taken together, the results obtained from this battery of robustness tests and alternative specifications are informative in interpreting the likely mechanism behind the relation between dividend policy and the presence of local seniors. For example, we find no relation between the presence of local seniors and share repurchases, investment, and net income, as would be predicted if the presence of local seniors were related to the presence of mature companies that generate high cash flows, but have limited investment opportunities. Rather, the only relation is with dividend policy. Our results are robust to a wide range of economic and demographic county-level controls and, thus, the correlation that we find between dividend payout policy and the presence of seniors in the community does not appear to be driven by firms in economically stagnating counties.

Implicit behind the dividend demand explanation is the presence of a market friction such as geographically segmented markets (for example, companies relying on "locals" as their shareholders/financiers). These frictions and, hence, local shareholders, probably are not equally important for all firms. In particular, we hypothesize that the dividend policy of four subsets of firms should display greater sensitivity to the presence of local seniors: (1) small companies (these companies generally are more reliant on local shareholder bases); (2) companies located in counties in which there is a strong preference for owning local stocks in general (unrelated to local seniors' demand for dividends); (3) banks (companies for which local seniors are likely to be important customers because they provide a large share of bank deposits, thus providing management a further incentive to appease any preference for dividends); and (4) companies located in communities with few other nearby companies around to satisfy 
local investors' demand for dividends (akin to the "only-game-in-town" effect of Hong, Kubik, and Stein (2008)). The supply-based alternative has no such predictions along these four dimensions because the supply of dividends (i.e., companies' ability to pay dividends) should not depend on the role of local senior investors. Consistent with the dividend-demand hypothesis, we find that the effect of Local Seniors is stronger for all four of the subsample splits identified above.

Finally, in the third tier of our identification strategy, we shed some light on an important piece of the puzzle-why managers may care about responding to this dividend demand. We find that local senior investors have lower stock turnover. That is, once senior investors buy shares of a local stock, they tend to hold the shares for a while, more than twice as long as average retail investors do. We also document valuation effects on the ex-dividend day that are consistent with the local seniors effect.

Overall, the analyses presented in this paper suggest that corporations' incentives to pay dividends depend on their location, and that this variation in incentives seems to affect dividend policy, particularly the decision to start paying dividends - a decision that has long-lasting consequences for the corporation. We can detect such effects on payout policy in a given cross-section because there is substantial variation in demographics across counties in the U.S. ${ }^{3}$ While the dividend-demand hypothesis has strong cross-sectional predictions (companies located in areas with a larger fraction of seniors are more likely to pay dividends), it is unlikely to have affected the aggregate time series of dividend payments. Over the period from 1980 to 2000, although the age structure of some counties has changed in a nontrivial way, the average fraction of seniors in the counties in which firms are located has changed little (from 11.1\% of a county's population in 1980 to 11.8\% in both 1990 and 2000). As Fama and French (2001) point out, changes in the industry composition of firms over time have led to a strong time-series decline in aggregate dividend payouts - this certainly overwhelms any demographic tendencies over the sample period.

Our result that investor preferences can be an important determinant of corporate decisions complements findings from several recent studies. For example, 
Allen, Bernardo, and Welch (2000) develop a theory of tax-based investor clienteles, predicting that dividends will be used as a tool to attract institutional investors. Our work is related to research on time-series variation in the demand for dividends (Baker and Wurgler (2004a, 2004b)). Similar to Baker and Wurgler, we conclude that dividend demand drives some part of the variation in payout policy (in our case, cross-sectional variation). Our paper is also related to Perez-Gonzales (2003) and Brown, Liang, and Weisbenner (2007), who examine firms' responses to tax changes based on the presence of large shareholders and CEOs as owners, respectively, examples of the type of research called for in Graham (2003). Similar to these papers, we conclude that owners matter for corporate policies, but, in this case, the owners of interest are retail investors. Finally, our results suggest that there is important geographical variation in the financial conditions that firms face, consistent with the findings reported in, for example, Jayaratne and Strahan (1996), Guiso, Sapienza, and Zingales (2004), Becker (2007), and Hong, Kubik, and Stein (2008).

The rest of the paper is organized as follows. Section I describes our data sources. Section II presents evidence on the effect of Local Seniors on firm dividend policy with several robustness checks. Section III describes evidence as to why managers may care about this dividend demand, and Section IV concludes.

\section{Data Sources and Main Sample Overview}

\section{A. Data Sources}

We compile data from several sources. Stock returns and ex-dividend date information come from the Center for Research in Security Prices (CRSP). Firm-level accounting information, as well as firm location information (the county in which the

headquarters are located), come from Compustat. Our use of the location of corporate headquarters follows previous studies in the locality literature (Coval and Moskowitz (1999, 2001) and Ivković and Weisbenner (2005)). 
Geographic data on seniors at the county level and other county-level demographic variables come from the 1980, 1990, and 2000 U.S. Censuses. As discussed in the introduction, we define the variable Local Seniors as the number of individuals aged 65 or older living in a county divided by the total population of that county. The Local Seniors variable is slow-moving and consecutive cross sections generally are very similar (the correlation between the county-level fraction of seniors in the 1990 and 2000 censuses is 0.94 , and the correlation between the 1980 and 2000 censuses is 0.84 ). We also collect median house prices, median income, and educational composition of the county (the fraction of the population completing grades 1-8, grades 9-11, high school, some college, and a bachelor's degree or higher) for each census year.

Some of our analyses involve the use of a data set on the positions and trades of tens of thousands of individuals made through a large discount broker over the period from 1991 to $1996 .{ }^{4}$ These data are used for two primary purposes. First, we use them to establish the degree of local bias that prevails in a county. Second, we use detailed trade data to draw inferences regarding the trading propensities of local seniors relative to those exhibited by other individual investors who invested through the discount broker.

In our analyses of dividend policy changes for companies that moved their corporate headquarters, we use Compact Disclosure to ascertain likely movers. The information provided through this data source was cross-checked with other sources to confirm the moves. ${ }^{5}$

\section{B. Main Sample Overview}

Table I presents summary statistics for payout policy variables and key countylevel variables. The sample consists of pooled cross-sections for 1980, 1990, and 2000. Summary statistics for the payout policy variables, expressed in percentage points, are presented in Panel A. The payout policy variables are defined as follows: Dividend Payer is an indicator variable equal to zero for non-payers and 100 for dividend payers; Dividend Initiation is an indicator variable, defined for non-payers at the end-of-year $t$, 
equal to zero for the companies that remain non-payers in year $t+1$ and 100 for companies that start to pay a dividend in year $t+1$; Dividend Yield is the dollar amount of dividends paid out in year $t+1$ as a percent of end-of-year $t$ equity market value; and Repurchase Yield is defined analogously for share repurchases in year $t+1$. All of our payout policy variables (our left-hand-side variables) are measured the year after our firm-level and county-level controls (the right-hand-side variables). Thus, the payouts in 1981, 1991, and 2001 are related to the firm- and county-level characteristics in the 1980, 1990, and 2000 cross-sections, respectively. The average value of 47.4 for the variable Dividend Payer indicates that $47.4 \%$ of our sample companies paid dividends in the following year. Further, $2.0 \%$ of our sample companies not paying dividends in a given year paid dividends the next year (Dividend Initiation). The average dividend yield across all firms (non-payers as well as payers) is 1.9\%, and the repurchase yield is $1.1 \%$.

\section{TABLE I ABOUT HERE}

Summary statistics for the key geographical variables are presented in Panel B of Table I. The Local Seniors variable (the proportion of a county's population aged 65 or older) averages 0.116 across all sample observations. The range is wide, from 0.022 to 0.321 , and the standard deviation is 0.031 . Aside from summary statistics on the proportion of seniors in counties, the table also lists summary statistics for the inverse of the number of firms in the county (the number of firms from Compustat with headquarters - "company location"-located in the county). The average is 0.102 (corresponding to 10 companies in the county), and the range is from 0.002 to 1.000 (corresponding to 500 companies and one company in the county, respectively).

\section{Results}

\section{A. Baseline Results}

Our baseline test of the hypothesis that local dividend demand determined by demographics helps explain corporate payout policy is to verify whether there is a 
positive relation between our three dividend payout policy variables and Local Seniors. In an ideal econometric framework, we would use Local Seniors as an instrument for dividend demand in payout policy regressions. Because we do not have an explicit measure for dividend demand, we instead estimate payout policy regressions with the Local Seniors variable (that is, we essentially estimate "reduced-form" regressions). We employ a linear-regression (OLS) framework on the sample of pooled observations from the 1980, 1990, and 2000 cross-sections, using three measures of dividends: an indicator variable for paying dividends (Dividend Payer), an indicator variable for paying dividends conditional on having not paid dividends in the previous fiscal year (Dividend Initiation), and the dividend yield variable (Dividend Yield). ${ }^{6}$ All of these dividend policy variables are expressed in percentage points.

Our payout policy dependent variables, defined in the previous section, are measured one year after Local Seniors and our firm-level controls. In addition to Local Seniors, all the specifications feature a number of other firm-specific controls. Net Income, Cash, and Debt (long-term) are all normalized by total assets. $Q$ is defined as the market-to-book ratio, that is, the market value of equity plus the book value of liabilities divided by the book value of assets. Volatility is the standard deviation of monthly stock returns over the preceding two years. Two-year Lagged Return is the monthly stock return over the preceding two years. Asset Growth is the logarithm of the growth rate of assets over the prior year. Age-group indicator variables (for corporations publicly listed for 1-5, 6-10, 11-15, and 16-20 years; the firms that have been publicly listed 21+ years are the omitted category), industry-year interaction indicator variables (fixed effects for two-digit SIC industries interacted with year), and state-year interaction indicator variables are also included in all three specifications. All independent variables, when appropriate, are winsorized at the 1st and 99th percentile levels.

State-year interaction indicator variables play a particularly important role because they absorb all variation in dividend behavior between states in a given year. This implies that none of our results are identified from differences across, for example, Florida and Utah, but, rather, from county-to-county variation within states. Similarly, 
industry-year interaction indicator variables ensure that our results are not identified from, for example, technology companies being located in areas with many young people and construction companies being located in areas with many seniors. Finally, we allow for heteroskedasticity and potential correlation across observations associated with the same firm when estimating the standard errors. Specifically, we use the HuberWhite sandwich estimator to estimate robust standard errors with clustering by firm.

\section{TABLE II ABOUT HERE}

The results are presented in Table II. Column (1) reports the results for the Dividend Payer dependent variable. The estimated coefficients pertaining to traditional independent variables line up with expectations and previous studies. For example, firm-level volatility, asset growth, and leverage all reduce the probability of paying dividends, while firm size (market value) and firm age increase the likelihood of paying dividends. The coefficient associated with Local Seniors is 59.3 and is highly statistically significant $(p$-value $<0.01)$. The interpretation of the coefficient is that moving from a county with no seniors to a county with only seniors increases the likelihood that the company pays dividends by 59.3 percentage points. Thus, although Local Seniors is a noisy proxy for dividend demand from shareholders, we find both statistically and economically significant effects of Local Seniors on corporate dividend policy.

Column (2) examines dividend initiations. The sample is smaller because it includes in each cross-section only the prior calendar year's non-dividend payers. The coefficient associated with Local Seniors is large and significant, implying that the probability of initiating dividends is much higher for corporations located in counties with a large fraction of seniors. The dependent variable in column (3) is Dividend Yield, that is, total dividend payout divided by market value (expressed in percentage points). Once again, Local Seniors has a positive and significant effect.

In the Internet Appendix, we provide the economic magnitude of the effects of Local Seniors and various firm-specific controls on company dividend policy by analyzing the predicted effect on dividends resulting from a one-standard deviation 
change in a particular variable (using the estimated coefficients from Table II). ${ }^{7}$ For the simple Dividend Payer variable, the effect of Local Seniors is larger than the effect of some firm characteristics commonly included in payout policy regressions, but it is smaller than the effect of stock return volatility, size, $Q$ (the market-to-book ratio), and leverage. A one-standard deviation increase in Local Seniors (0.031) boosts the likelihood of paying dividends by 1.8 percentage points, or $4 \%$ of the sample average likelihood of paying dividends. Further, a one-standard deviation increase in Local Seniors is associated with an increase in the dividend yield of $0.23 \%$, a $12 \%$ increase relative to the sample average yield of $1.9 \%$.

Particularly striking is the economic magnitude of the effect of Local Seniors on the dividend initiation decision. An increase of one standard deviation in Local Seniors is associated with a 1.0 percentage-point increase in the probability of dividend initiation for non-payers, an economically substantial effect that is equal to one-half of the average rate of initiation of $2.0 \%$ over the sample. To put this effect of Local Seniors on dividend initiations into perspective, it is of the same magnitude as a one-standard deviation increase in firm size (market capitalization) or the time since the firm's public listing increasing from 6-10 years to 16-20 years (which is associated with a 1.1 percentage-point increase in the likelihood of the firm starting to pay dividends). The effect of a one-standard deviation increase in Local Seniors is twice the magnitude of one-standard deviation changes in cash holdings, debt, volatility, and prior two-year returns.

These results provide evidence of an effect of Local Seniors on dividend policy. ${ }^{8}$ The estimated coefficients suggest an economically important relation between corporate payout behavior and local dividend demand, particularly for dividend initiations. Given the stickiness of dividend policy, understanding what causes companies to start paying dividends in the first place is crucial for better understanding why they are paying dividends today. 
Whereas these findings are consistent with individual investor demand driving corporate payout policy decisions, this clearly is not the only plausible interpretation of our results. We next consider potential alternative explanations.

\section{B. Toward Ruling Out a Supply-Based Alternative Hypothesis}

Having established the baseline result, namely, a strong correlation between dividend payout behavior and Local Seniors, we proceed with the second tier of our identification strategy, in an effort to differentiate our demand-based explanation from the supply-based alternative theory. It is possible that some omitted variable, correlated with Local Seniors, might be the true driver of dividend policy. For example, Local Seniors might proxy for areas with low growth prospects and, perhaps, high profitability. A supply-based alternative explanation would suggest that companies located in counties with many seniors might have high profitability, low investment, and high payouts (perhaps in terms of both dividends and share repurchases). On the other hand, our demand-based hypothesis predicts a positive effect of Local Seniors on dividends, as established in the previous section, and no effect of Local Seniors on company characteristics or policies affected by supply-based alternatives such as share repurchases, profits, and investment.

To differentiate between these alternative explanations, we relate share repurchase behavior, investment, and net income to Local Seniors (as well as the same set of independent variables as in the analyses reported in Table II and discussed in the previous subsection). The dependent variables in these analyses are Repurchase Yield (the dollar amount of stock repurchases made in year $t+1$ as a percent of end-of-year $t$ equity market value), Investment (capital expenditure in year $t+1$ as a percent of end-ofyear $t$ assets), and Net Income (net income in year $t+1$ as a percent of end-of-year $t$ assets).

In short, the results, presented in Table III, do not offer any support for the supply-based alternative. Indeed, there is no effect of Local Seniors on the Repurchase Yield (either measured over the next year or averaged across the next three years to 
address fluctuations in share repurchases on a year-to-year basis), Investment, or Net Income.

\section{TABLE III ABOUT HERE}

\section{Economically Growing Areas and Additional County-Level Controls}

Another way to differentiate between demand- and supply-based explanations is to consider local economic environments likely to be growing (or, at least, not stagnating). Governed by the notion that a decline in the total number of young residents (those younger than 40 years of age) in the county since the last census is a proxy for economic stagnation (for example, rural, declining areas with mature, "oldeconomy" companies), for the purposes of these analyses we remove observations associated with such county-year combinations from the sample. ${ }^{9}$ That is, in a given cross-section, we drop firms located in counties in which the fraction of seniors may be high because young people left to find better opportunities elsewhere. If the relation between dividends and the presence of local seniors is driven by mature firms in declining areas, the effect of Local Seniors should disappear when estimated over the "growing" subsample. The demand-based explanation, however, still applies in the remaining sample and thus predicts a positive relation between dividends and Local Seniors.

Table IV features the results of regressions by subsample. For ease of comparison, columns (1), (4), and (7) replicate Table II. The columns featuring regressions analogous to those reported in Table II, but estimated over the growingcounty subsample-columns (2), (5), and (8)-report coefficients associated with Local Seniors that are similar in magnitude to those resulting from the estimation based upon the full sample (and are also highly statistically significant).

\section{TABLE IV ABOUT HERE}

Returning to the full sample, a further robustness test serves to alleviate the concern that Local Seniors might proxy for some observable demographic and economic 
variables that capture the local environment in which firms operate. The remaining three columns in Table IV-columns (3), (6), and (9) - feature the results based upon such a specification, in which the set of independent variables has been augmented by additional demographic controls (logarithm of county population and the educational composition of the county - the fraction of the population having finished college, the fraction having finished high school, and so on) and economic controls (the average of each of the firm-level variables across all companies located in the county, as well as the share of local companies in each industry as classified by two-digit SIC code, median house prices in the county, and median income in the county). Once again, the regression coefficients are quite similar, in terms of both magnitude and significance, to those resulting from the baseline specification.

\section{Differences in Companies' Responses to Local Dividend Demand}

As discussed in the introduction, the relation between corporate policy and the preferences of the local community likely varies across firms. In particular, we hypothesize that the dividend policy of four subsets of firms should display greater sensitivity to the presence of local seniors. The first subset consists of small corporations, companies generally more reliant on local shareholder bases. The second subset comprises firms located in counties in which there is a strong preference for owning local stocks in general (unrelated to local seniors' demand for dividends). The third subset consists of corporations in the banking industry, a subset of firms for which local seniors likely also are important customers because they provide a large share of bank deposits (thus providing further incentive to appease any preference for dividends)..$^{10}$ Finally, the fourth subset comprises companies located in counties with few other nearby corporations around to satisfy local investors' dividend demand (akin to the "only-game-in-town" effect of Hong, Kubik, and Stein (2008)). The supply-based alternative has no such predictions along these four dimensions because the supply of dividends (that is, companies' ability to pay dividends) should not depend upon the role of local investors. 
Table V presents the results. The first column restates the baseline estimate of the Local Seniors coefficient from Table II. In addition to all the independent variables from the baseline specification, these analyses feature three indicator variables. The first indicator variable, featured in column (2), is Small Firm; it is equal to one for firms with below-median market capitalization, and zero otherwise. The second indicator variable, featured in column (3), is High Local Bias County; it is equal to one if the company is headquartered in a county in which the extent of local bias among the non-senior local retail investors from the brokerage data sample is above the median, and zero otherwise. ${ }^{11}$ The third indicator variable, featured in column (4), is Bank; it is equal to one for firms in the banking industry (two-digit SIC equal to 60), and zero otherwise.

\section{TABLE V ABOUT HERE}

The results presented in column (2) line up with the predictions very closelythe effect of Local Seniors is concentrated among small companies (there is essentially no effect for large companies, with a point estimate of 7.6; $\mathrm{SE}=24.0$ ), with a highly statistically significant point estimate of 99.8 for the total effect of Local Seniors for small firms (the baseline effect of Local Seniors, 7.6, plus the interaction of Local Seniors and Small Firm, 92.2, gives the total effect of Local Seniors for small firms). Similarly, column (3) shows that the effect is concentrated among companies headquartered in high localbias counties. The total effect of Local Seniors for firms in high local-bias counties is 144.0, with a high level of statistical significance.

Next, we consider banks. Banks have a particularly relevant feature-local seniors likely are important customers of the firm. As Becker (2007) documents, seniors are important among banks' retail customers. Compared with other age groups, seniors tilt their financial portfolios disproportionately toward bank deposits-they are the only age group in which more than $90 \%$ of individuals have transaction accounts and in which more than $20 \%$ hold certificates of deposit (CDs). Moreover, seniors have much higher mean and median shares of their wealth held in checking accounts, saving accounts, and CDs than any other age group (Becker (2007, Figure 1)). Because of these 
patterns, and seniors' higher financial wealth, although their population fraction is only $12 \%$, seniors own $33 \%$ of total household money in checking accounts, $27 \%$ of the money in savings accounts, and $37 \%$ of the money in CDs (even though they receive only about $14 \%$ of total income, including pensions), and hold $25 \%$ of total household wealth. ${ }^{12}$

The median distance between a borrower and a bank over the period from 1973 to 1993 is no more than five miles (Petersen and Rajan (2002)). Assuming the same closeness exists for the bank-depositor relationship, there potentially is a significant cost associated with not considering local seniors' demand for dividends-the risk of not only making local seniors unhappy as shareholders, but also as depositors, that is, bank customers (with a credible threat that such unsatisfied local seniors might withdraw their deposits and bank elsewhere).

According to column (4) of Table V, as predicted, the effect of Local Seniors is about two and one-half times larger for banks than it is for other companies. The coefficient associated with the total effect of Local Seniors on banks is 134.5 and is highly statistically significant, whereas the effect of Local Seniors on other firms is 52.2 (still significant in its own right); the difference between the two is statistically significant at the $5 \%$ level.

We conclude this section with a test of whether local dividend demand matters more for companies in counties with fewer surrounding firms, in the spirit of the "onlygame-in-town" effect of Hong, Kubik, and Stein (2008), who find that companies located in areas with fewer other firms around receive higher valuations. We extend their study with an inquiry into whether such an effect is present for dividend policy. If local seniors demand a certain level of dividends (or dividend-paying stocks in their portfolio) and they look to local companies to satisfy their demand, then their dividend demand should be stronger for a given firm when that firm is surrounded by few other companies in the county. The results, presented in column (5) of Table V, suggest that the effect of Local Seniors indeed is stronger in counties with a lower density of companies. Specifically, the effect of the interaction between Local Seniors and the 
inverse of the number of firms in the county is positive, large in magnitude, and highly statistically significant.

\section{E. County-level Fixed Effects}

We next employ analyses that represent a much higher hurdle to identify the local seniors effect. The first such analysis is analogous to the baseline analysis (see Section II.A and Table II), with the addition of fixed effects at the county level. Thus, the identification of the effect of Local Seniors on dividend policy comes from changes in the fraction of seniors in the county (controlling, as before, for all other firm-specific factors that may vary over time). In other words, the coefficient associated with Local Seniors in this specification is identified from the payout policy decisions of companies headquartered in counties in which the age composition is changing over time. We first apply this county-level fixed effects specification on the full sample, and then obtain the relation between dividend policy and Local Seniors for three subsets of firms where we would expect to find a more pronounced relation.

The coefficient associated with Local Seniors from the Dividend Payer county-level

fixed effects regression is $64.4(\mathrm{SE}=51.0)$ for the full sample of firms. The magnitude of the effect is similar to that reported in the cross-sectional regression in Table II but the $p$ value of the coefficient is 0.21 . However, there are marginally significant effects for three subsamples among which, a priori, the dividend demand motivation should be strong - small companies (coefficient $=114.8, \mathrm{SE}=64.8, p<0.10$ ), companies in counties in which the residents have high local-bias tendencies in their portfolios (coefficient $=$ 213.5, $\mathrm{SE}=86.5, p<0.05$ ), and banks (coefficient $=112.4, \mathrm{SE}=67.7, p<0.10$ ).

\section{F. Corporate Headquarter Moves}

As a further source of identification, we consider the subset of firms that moved their corporate headquarters to a different state, a proxy for sufficient distance to assume comfortably that the two local individual investor pools (the "old" one and the "new" one) are not overlapping. We examine a sample of just under 150 such companies, obtained from Compact Disclosure, that moved their corporate 
headquarters in the period from 1997 to 2000 and that have sufficient data pre- and post-move to conduct our analyses. ${ }^{13}$

The analyses relate changes in dividend policy in the aftermath of the move (relative to the dividend policy in effect before the move) to changes in the proportion of seniors across the new and old communities, controlling also for changes in the other firm characteristics over the same time period. For the purposes of these analyses, we incorporate observations in off-Census years that occurred both before and after the move. For such observations, we use linear interpolations of Census figures from the 1990 and 2000 Censuses (and extrapolations for years after 2000). For a company that moved its headquarters, for example, some time between 1999 and 2000 (the company has an address in a different state in 2000 compared to 1999 in Compact Disclosure), we record whether it paid dividends in 1998, one full year before the move (recording firm characteristics and the fraction of seniors in the "old" community at that time) and whether it paid dividends after moving to its new location (recording firm characteristics and the fraction of local seniors at the "new" community). We measure whether the company paid dividends one to five years after the move-in the 2000 move example, the first full year after the move would be 2001, and the fifth year after the move would be 2005 .

Column (1) of Table VI presents the results, provided in five panels that allow for increasingly longer post-move periods, ranging from one to five years. ${ }^{14}$ Two key results stand out. First, even for a one-year post-move horizon, there is a strong relation between the change in dividend-payer status and the change in Local Seniors (the point estimate, 111.2 , is large and statistically significant at the $5 \%$ level). Second, perhaps not surprisingly, the effect strengthens as the post-move horizon increases; the effect of Local Seniors roughly doubles for the three-year horizon, and increases still further to 343.2 for the five-year horizon (statistically significant at the $1 \%$ level). A firm moving to a county in which Local Seniors is one standard deviation higher than it was at its original location (that is, Local Seniors increases by 0.031 ) is 3.4 percentage points more likely to be a dividend payer one year after the move, 5.9 percentage points more likely 
to be a dividend payer three years after the move, and 10.6 percentage points more likely to be a dividend payer five years after the move.

\section{TABLE VI ABOUT HERE}

The second column features the complete sample of corporations in existence during the pre- and post-move years of the 1997 to 2000 sample of movers. To be specific, whereas in the first column we relate changes in dividend policy to changes in Local Seniors and firm-level characteristics for the sample of movers only, in column (2) we also include in the regression changes in dividend policy and firm-level characteristics for the non-moving companies over the same time period. Aside from testing whether a change in Local Seniors affects the dividend policy of moving companies, the specifications in column (2) allow us to test further whether the change in dividend policy differs across mover and non-mover companies (also controlling for the effect of changes in firm-specific characteristics on both movers and non-movers). These specifications thus include the indicator variable Firm Moved (equal to one if the company's headquarters moved in year $t$, and zero otherwise). The findings offer additional reassurance-by itself, the fact that the company headquarter locations have changed (controlling for everything else, of course) plays little role in the change in dividend policy. ${ }^{15}$ Moreover, the size and significance level of the coefficients associated with Local Seniors are highly comparable across the two analyses.

Naturally, the small sample size of the set of movers calls for caution in interpreting these results and, thus, in extrapolating these results to the general population of firms. Nonetheless, the direction, magnitude, and significance of these results all line up in a manner consistent with the dividend demand hypothesis and our results presented elsewhere in the paper, thus offering complementary evidence based on an entirely different identification strategy. 


\section{Potential Benefits of Satisfying Local Dividend Demand}

Having found effects consistent with the dividend demand hypothesis, we proceed with the third and final tier of our identification strategy. In this section, we explore why managers might wish to respond to local seniors' demand for dividends, ${ }^{16}$ whether there are benefits to such demand-induced payouts, as well as the mechanisms through which individual investor demand may affect corporate policy. We consider two possible channels and offer suggestive evidence. At the outset, we remark that the channels we discuss in this section are not mutually exclusive. Moreover, none of these channels require that managers be explicitly informed about local retail investors' age, or that they should feel goodwill toward local investors in general or local seniors in particular.

\section{A. Lower Turnover}

Graham and Kumar (2006) report that seniors are more likely to buy dividendpaying stocks in the two weeks leading up to the ex-dividend day, and are more likely to buy stocks after they start to pay dividends. We use the same brokerage data as in Graham and Kumar (2006) and build upon their result that seniors buy stocks after a company initiates dividends (or just before a company is to pay dividends) by studying individuals' propensity to sell a stock they hold already (i.e., what local seniors do after they buy the stock). The brokerage data are extremely well suited for this purpose-to study the sale decision of a given investor and a given stock holding. That is, the many observations of potential sale behavior across many investors enable us to obtain strong and robust results regarding holding periods. We can thus ascertain, with a high degree of precision, what happens once investors purchase stock-given their characteristics (in this case geographic location and age), whether they are more likely, relative to others, to keep on holding the stock.

We test whether, conditional on owning the stock, local seniors have a substantially longer holding period than other types of investors do. This lower turnover may be attractive to company management, and a way to attract such loyal 
investors to own the stock in the first place is to pay dividends. To test the "lower turnover" channel, we first conduct a completely nonparametric analysis in which we estimate the cumulative likelihood of sale of a given stock holding for four investor groups (comprising just over 30,000 households): potential sales by all individuals, potential sales by seniors (65 years of age or older), potential sales by local investors (the distance between the household and corporate headquarters is 250 miles or fewer - the local-distance metric used in Ivković and Weisbenner (2005)), and potential sales by local senior investors.

Tallying the sales made in a given month since purchase relative to the total number of potential sales at the beginning of the month produces nonparametric hazard rates for each month (i.e., the probability of selling in that month conditional on not having sold the stock up to that point), and cumulating those monthly hazard rates yields the cumulative probability distribution of sale as a function of time since purchase. The four cumulative probability distributions are presented in Figure 1. Whereas the median holding period for all investors (the first sample) is 15 months, the median holding period for local-senior investors (the fourth sample) is substantially longer, 37 months.

\section{FIGURE 1 ABOUT HERE}

This analysis, though compelling, does not take into consideration other potential motivations for sale, including stock performance since purchase, nor potential selection issues based on preferences for holding different kinds of stocks (each of which, by themselves, could lead to different selling patterns across individuals). Therefore, we also conduct a more stringent analysis by incorporating several covariates that capture investor sensitivity to past performance (be it for behavioral reasons or tax motivations).

Our econometric framework for these analyses follows Ivković, Poterba, and Weisbenner (2005) closely. We use the Cox proportional hazards model, which employs nonparametric estimates of baseline monthly hazards (that is, the probabilities of selling 
the stock in month $t$ after purchase, conditional on no prior sale). The results of the Cox proportional hazards model, presented in the Internet Appendix, confirm the differences in the likelihood of selling stock displayed in Figure 1. According to the estimates from the more rigorous proportional hazards model analyses, during a month, a local senior investor is $28 \%$ to $32 \%$ less likely to sell a share of stock than a non-local non-senior investor is. Aggregated over time, this difference results in much longer holding periods and much lower turnover for the group of investors who likely are attracted to purchase the stock of firms that pay dividends.

\section{B. Price Channel-Ex-Dividend Day Reaction}

Our second line of inquiry considers valuation effects. Our identification strategy studies stock price movements around the ex-dividend day. ${ }^{17}$ We relate ex-dividend day returns to Local Seniors, a technique used previously to infer marginal tax rates (see, for example, Elton and Gruber (1970), Perez-Gonzales (2003), and Graham and Kumar (2006)), as well as dividend demand valuation effects for non-tax reasons (Graham and Kumar (2006)). Elton and Gruber (1970) divide ex-dividend price drops by the amount of the dividend and report that this ratio averages 0.78. Depending on the subpopulation of corporations they consider, Graham and Kumar (2006) report that this ratio in their study averages from 0.67 to 0.79 . The price drop is less than the dividend paid, presumably because, for many investors, dividends face higher taxes than capital gains do. As Elton and Gruber (1970) point out, in a rational market, the price drop when the stock goes ex-dividend reflects the relative value of dividends and capital gains to the marginal stockholders. Thus, a company whose owners face a lower dividend tax rate (or a higher tax rate on capital gains) should experience a bigger drop in the share price when the stock goes ex-dividend.

We apply a similar logic to the firms facing investors with a dividend preference: the ex-dividend day price drop, as a fraction of the dividend amount, should be large when demand for dividends is high. As before, we use Local Seniors to proxy for

dividend demand. Alternative explanations for our findings on payout policy (for 
example, that Local Seniors proxies for local economic conditions that lead to dividend supply by firms) do not predict such a relation between ex-dividend day price behavior and Local Seniors.

We adjust the ex-dividend methodology of Elton and Gruber (1970) along two dimensions. First, we use price changes from market close on the last cum-dividend day to the opening trade the following, ex-dividend day, and thereby focus more narrowly on the price change related to the loss of the dividend right. This mitigates the risk of confounding the inference with the price changes taking place during the following, exdividend day. Second, whereas the original Elton and Gruber (1970) methodology normalizes the price change by the dividend amount, our dependent variable is the relative price drop - the negative of the price change from the close of the last cumdividend day to the open of the ex-dividend day divided by the closing price on the last cum-dividend day. ${ }^{18}$ Accordingly, our independent variables are the dividend amount scaled by the closing price, Local Seniors, and the interaction between the two (we also include Median Income, the median income of the county in which the company is headquartered and its interaction with the amount of the dividend).${ }^{19}$ We estimate these regressions over the sample of stock returns surrounding ex-dividend days in the period from 1992 to 2007. Local Seniors and Median Income in off-census years are estimated by linear interpolation (and extrapolation) of the figures from the Census years.

Table VII reports the results. The first column provides a simple gauge; it features only $\operatorname{Div}_{i, t} / P_{i, t-1}^{\text {close }}$ (abbreviated in the table as $\operatorname{Div} / P$ for readability). The regression coefficient estimate is 0.73 , suggesting that, absent further controls, a onedollar dividend is associated with a 73-cent price drop on the ex-dividend day, a figure that is very similar to the baseline figures from Elton and Gruber (1970) and Graham and Kumar (2006).

\section{TABLE VII ABOUT HERE}


The second column features $\operatorname{Div}_{i, t} / P_{i, t-1}^{\text {close }}$ and its interaction with the indicator variable Small Firm (defined as in Table V), thereby allowing for differential valuations of dividends across the shareholders of small and large corporations. The results match intuition and extant findings very well. For large companies, the price drop on the exdividend day associated with a one-dollar dividend is 86 cents, whereas for smaller companies, more likely to be held by individuals and thus more likely to be subject to higher marginal tax rates, the price drop is 60 cents (the difference between the two is 26 cents, statistically significant at the $1 \%$ level).

In the third column, we present evidence that the ex-dividend day price drop, that is, the valuation of dividends, varies across communities. We add to the specification Local Seniors, the interaction Div/P x Local Seniors, Median Income, and the interaction Div/P x Median Income. In light of our primary interest in how community characteristics affect the relation between the ex-dividend day price drop and the amount of the dividend (that is, the interactions of Local Seniors and Median Income with Div/P), the coefficients associated with Local Seniors and Median Income themselves are suppressed from the table for readability. ${ }^{20}$ Median Income, measured at the county level, is a geographically-based measure of income intended to capture tax-related motivations from potential local shareholders. Consistent with seniors' demand for dividends, the price drop is positively related to Local Seniors (the coefficient estimate is 3.0, statistically significant at the $10 \%$ level), that is, the ex-dividend day price drop is larger in areas with a higher fraction of seniors. The magnitude of this effect is substantial-a one-standard deviation increase in Local Seniors is associated with an increase in the ex-dividend day price drop as a fraction of the dividend of 0.09 , or oneeighth of the average price drop from column (1).

The relation between the ex-dividend day price drop and the interaction Div/P $\mathrm{x}$ Median Income is negative and statistically significant, consistent with smaller exdividend day price drops in regions in which income and, presumably, tax rates are higher. This result is consistent with marginal investors of at least some corporations 
being local individuals (and, thus, whether a firm is located in a community in which individuals have high income and high tax rates affects the valuation of the firm's dividends on the ex-dividend day). However, given the unit of measurement of Median Income (in units of $\$ 100,000$ ), its economic importance is very modest (a one-standard deviation increase in the median income of the county, $\$ 15,500$ in our sample, is associated with an ex-dividend day price drop as a fraction of the dividend that is only 0.01 smaller).

Finally, in the fourth column all the variables from the third column are interacted with the indicator variable Small Firm (defined as in Table V) to allow for differential effects across small and large companies. ${ }^{21}$ Our prediction is that the sensitivity of the valuation of dividends to Local Seniors should be stronger for small firms than for large firms. This is exactly what we find. As shown in column (4), there is no relation between the ex-dividend day price drop and the presence of local seniors in the community (or the median income of the county) for large corporations. Adding the coefficients on Div/P x Local Seniors and Div/P x Local Seniors $\times$ Small Firm provides the total effect of Local Seniors on the ex-dividend day price drop for small stocks. Compared to the estimate across all stocks of 3.0 from column (2), the effect for small stocks is larger, 4.7 (statistically significant at the $10 \%$ level; the associated $p$-value is 0.06). Moreover, for small stocks a one standard deviation increase in Local Seniors is associated with an increase in the ex-dividend day price drop as a fraction of the dividend of 0.15 , one-quarter of the average price drop from column (2). For small companies, which are more likely to rely on local shareholders, the ex-dividend price drop is also related to the median income of the county in which the company is headquartered in the direction predicted, but the economic magnitude of this local income effect again is very small.

In sum, these results extend the findings from Graham and Kumar (2006), who show that the price fall on the ex-dividend day is positively related to the age of the shareholders of the firm and negatively related to the income of the shareholders of the firm. Our ex-dividend results are consistent with the notion that companies located in 
counties with higher fractions of seniors face stronger demand for dividends, and that such demand is associated with larger stock-price drops on ex-dividend days, but only for small companies, which are more likely to be affected by this geographically varying demand for dividends from the local senior population. The valuation effects detected on the ex-dividend day and the prior evidence concerning lower turnover, while each suggestive on their own, together reinforce the dividend demand hypothesis. Moreover, neither channel requires that managers be explicitly informed about local retail investors' age.

\section{Conclusion}

Miller and Modigliani (1961) raise the question of whether firms set policies and investors sort accordingly, or whether companies respond to the preferences of their current shareholders. In this paper, we provide evidence consistent with the latter. Specifically, we test for the effect of dividend demand on payout policy. The tendency of older investors to hold dividend-paying stocks in combination with individual investors' inclination to hold local stocks results in stronger dividend demand for companies located in areas with many seniors. Demographics thus provide an empirical proxy for dividend demand, which we exploit in this paper to examine the broader question of whether the preferences of current owners influence corporate actions.

As predicted, we find a significant positive effect of Local Seniors, the fraction of seniors in the county in which a firm is located, on the firm's propensity to pay dividends, its propensity to initiate dividends, and its dividend yield. The effect of Local Seniors on the corporate decision to start paying dividends is particularly strong, of the same economic magnitude as other key determinants such as company size and age.

Because demographics are only a rough proxy for demand, our results can be interpreted as placing a lower bound on the effect of investor preferences on payout policy. If there are other components of demand, the total effect of investor preferences on corporate policies may be larger. Our results are robust to various methodologies and identification strategies, and are not supportive of alternative explanations (for 
example, that firms located in areas with many seniors have low growth opportunities and, therefore, are more likely to pay out cash to shareholders).

The main implication of our findings is that, at least to some extent, corporations respond to the preferences of their owners when setting payout policy. We confirm that age determines dividend demand, consistent with the hypothesis of Miller and Modigliani (1961) and the evidence presented in Graham and Kumar (2006). We further show that there are dividend clienteles that vary geographically, creating differences in demand for dividends across firms that help explain some of the substantial crosssectional heterogeneity as to why some companies pay dividends while others do not. Our findings thus suggest that there is important geographical variation in the financial conditions that firms face. 


\section{REFERENCES}

Allen, Franklin, Antonio E. Bernardo, and Ivo Welch, 2000, A theory of dividends based on tax clienteles, Journal of Finance 55, 2499-2536.

Baker, Malcolm, and Jeffrey Wurgler, 2004a, A catering theory of dividends, Journal of Finance 59, 1125-1165.

Baker, Malcolm, and Jeffrey Wurgler, 2004b, Appearing and disappearing dividends: The link to catering incentives, Journal of Financial Economics 73, 271-288.

Barber, Brad, and Terrance Odean, 2000, Trading is hazardous to your wealth: The common stock investment performance of individual investors, Journal of Finance $55,773-806$.

Becker, Bo, 2007, Geographical segmentation of US capital markets, Journal of Financial Economics 85, 151-178.

Brav, Alon, John R. Graham, Campbell R. Harvey, and Roni Michaely, 2005, Payout policy in the 21st century, Journal of Financial Economics 77, 483-527.

Brown, Jeffrey, Nellie Liang, and Scott Weisbenner, 2007, Executive financial incentives and payout policy: Firm responses to the 2003 dividend tax cut, Journal of Finance 62, 1935-1965.

Coval, Joshua D., and Tobias J. Moskowitz, 1999, Home bias at home: Local equity preference in domestic portfolios, Journal of Finance 54, 1-39.

Coval, Joshua D., and Tobias J. Moskowitz, 2001, The geography of investment: Informed trading and asset prices, Journal of Political Economy 109, 811-841.

Elton, Edward J., and Martin J. Gruber, 1970, Marginal stockholder clientele effect, Review of Economics and Statistics 52, 68-74.

Fama, Eugene F., and Kenneth R. French, 2001, Disappearing dividends: Changing firm characteristics or lower propensity to pay? Journal of Financial Economics 60, 3-43.

Graham, John R., 2003, Taxes and corporate finance: A review, Review of Financial Studies 16, 1074-1128.

Graham, John R., and Alok Kumar, 2006, Do dividend clienteles exist? Evidence on dividend preferences of retail investors, Journal of Finance 59, 1125-1165. 
Grinblatt, Mark, and Matti Keloharju, 2001, How distance, language, and culture influence stockholdings and trades, Journal of Finance 56, 1053-1073.

Guiso, Luigi, Paola Sapienza, and Luigi Zingales, 2004, Does local financial development matter? Quarterly Journal of Economics 119, 929-969.

Hong, Harrison, Jeffrey Kubik, and Jeremy Stein, 2008, The only game in town: Stockprice consequences of local bias, Journal of Financial Economics 90, 20-37.

Huberman, Gur, 2001, Familiarity breeds investment, Review of Financial Studies 14, 659680.

Ivković, Zoran, James Poterba, and Scott Weisbenner, 2005, Tax-motivated trading by individual investors, American Economic Review 95, 1605-1630.

Ivković, Zoran, and Scott Weisbenner, 2005, Local does as local is: Information content of the geography of individual investors' common stock investments, Journal of Finance 60, 267-306.

Jayaratne, Jith, and Philip Strahan, 1996, The finance-growth Nexus: Evidence from bank branch deregulation, Quarterly Journal of Economics 111, 639-670.

Lintner, John, 1956, Distribution of incomes of corporations among dividends, retained earnings, and taxes, American Economic Review 46, 97-113.

Loughran, Tim, and Paul Schulz, 2005, Liquidity: Urban versus rural firms, Journal of Financial Economics 78, 341-374.

Massa, Massimo, and Andrei Simonov, 2006, Hedging, familiarity and portfolio choice, Review of Financial Studies 19, 633-685.

Miller, Merton H., and Franco Modigliani, 1961, Dividend policy, growth, and the valuation of shares, Journal of Business 34, 411-433.

Perez-Gonzales, Francisco, 2003, Large shareholders and dividends: Evidence from U.S. tax reforms, Working paper, Stanford University.

Peterson, Mitchell A., and Raghuram G. Rajan, 2002, Does distance still matter? The information revolution in small business lending, Journal of Finance 57, 2533-2570.

Pirinsky, Christo, and Quinghai Wang, 2006, Does corporate headquarters location matter for stock returns? Journal of Finance 61, 1991-2015. 
Scholz, John K., 1992, A direct examination of the dividend clientele hypothesis, Journal of Public Economics 49, 261-285.

Shefrin, Hersh, and Meir Statman, 1984, Explaining investor preference for cash dividends, Journal of Financial Economics 13, 253-282.

Shefrin, Hersh, and Richard H. Thaler, 1988, The behavioral life-cycle hypothesis, Economic Inquiry 26, 609-643.

Thaler, Richard H., and Hersh M. Shefrin, 1981, An economic theory of self-control, Journal of Political Economy 89, 392-406. 


\section{Table I}

\section{Summary Statistics for Payout Policy Variables and Key County-Level Variables}

The sample consists of the pooled cross-sections for 1980, 1990, and 2000. Summary statistics for payout policy variables are presented in Panel A. Dividend Payer is an indicator variable equal to zero for non-payers and 100 for dividend payers. Dividend Initiation is an indicator variable defined for non-payers at the end-of-year $t$. Its values are zero for the firms that remain nonpayers in year $t+1$, and 100 for non-payers at the end of year $t$ who start to pay a dividend in year $t+1$. Dividend Yield is the dollar amount of dividends paid out in year $t+1$ divided by endof-year $t$ equity market value. Repurchase Yield is defined analogously for share repurchases in year $t+1$. Summary statistics for key geographical variables are presented in Panel B. Aside from summary statistics pertaining to Local Seniors (the proportion of residents who are 65 years old or older in the county in which a firm is headquartered, as reported by the U.S. Census Bureau), the table also lists summary statistics for the number of firms in the county (firms with their headquarters located in the county).

Panel A: Summary Statistics for Payout Policy Variables (in percentage points)

\begin{tabular}{lccccc}
\hline & Mean & $\begin{array}{c}2^{\text {th }} \\
\text { Percentile }\end{array}$ & Median & $\begin{array}{c}7^{\text {th }} \\
\text { Percentile }\end{array}$ & $\begin{array}{c}\text { Standard } \\
\text { Deviation }\end{array}$ \\
\hline Dividend Payer & 47.4 & 0 & 0 & 100 & 49.9 \\
Dividend Initiation & 2.0 & 0 & 0 & 0 & 14.2 \\
Dividend Yield & 1.9 & 0 & 0 & 3.0 & 3.7 \\
Repurchase Yield & 1.1 & 0 & 0 & 0.4 & 3.9 \\
\hline
\end{tabular}

Panel B: Summary Statistics for Key County-Level Variables

\begin{tabular}{|c|c|c|c|c|c|c|c|}
\hline & Mean & Min. & $25^{\text {th }} \%$ & Median & $75^{\text {th }} \%$ & Max. & Std. Dev. \\
\hline $\begin{array}{l}\text { Local Seniors } \\
\text { (Proportion } 65 \text { years }+ \text { ) }\end{array}$ & 0.116 & 0.022 & 0.097 & 0.115 & 0.132 & 0.321 & 0.031 \\
\hline $\begin{array}{l}\text { Inverse of Number of } \\
\text { Firms in County }\end{array}$ & 0.102 & 0.002 & 0.008 & 0.022 & 0.059 & 1.000 & 0.220 \\
\hline
\end{tabular}




\section{Table II \\ Dividend Payout and Local Seniors}

This table presents OLS regression results for firm dividend payout behavior, estimated over the sample of pooled observations from the 1980, 1990, and 2000 cross-sections. Dependent variables are measured one year after the firm- and the county-level controls (in 1981, 1991, and 2001, respectively). Dividend Payer is an indicator variable equal to zero for non-payers and to 100 for dividend payers. Dividend Initiation is an indicator variable defined for non-payers at the end-of-year $t$. Its values are zero for the firms that remain non-payers in year $t+1$, and 100 for non-payers at the end-of-year $t$ who start to pay a dividend in year $t+1$. Dividend Yield is the dollar amount of dividends paid out in year $t+1$ divided by the end-of-year $t$ equity market value. Our key independent variable is Local Seniors, the fraction of residents who are 65 years old or older in the county in which a firm is headquartered, as reported by the U.S. Census Bureau. Besides Local Seniors, the regressions include firm-specific controls. Net Income, Cash, and Debt (long-term) are all normalized by total assets. $Q$ is defined as the market-to-book ratio, that is, the market value of equity plus the book value of liabilities (using the book value of liabilities as an approximation for the market value of liabilities) divided by the book value of assets. Volatility refers to the standard deviation of monthly stock returns over the preceding two years. Two-year Lagged Return refers to monthly stock returns over the preceding two years. Asset Growth is the logarithm of the growth rate of assets over the prior year. Age-group indicator variables (for corporations publicly listed for 1-5, 6-10, 11-15, and 16-20 years; the firms that have been publicly listed 21+ years are the omitted category), industry-year interaction indicator variables (fixed effects for two-digit SIC industries interacted with year), and state-year interaction indicator variables are included in all three specifications. Standard errors (shown in parentheses) allow for heteroskedasticity and are clustered by firm. ${ }^{* * *}$, ** * denote significance at the 1 percent, 5 percent, and 10 percent levels, respectively. 


\section{Table II}

Dividend Payout and Local Seniors (continued)

\begin{tabular}{|c|c|c|c|}
\hline & $\begin{array}{c}\text { (1) } \\
\text { Dividend } \\
\text { Payer }\end{array}$ & $\begin{array}{c}\text { (2) } \\
\text { Dividend } \\
\text { Initiation }\end{array}$ & $\begin{array}{l}(3) \\
\text { Dividend } \\
\text { Yield }\end{array}$ \\
\hline Local Seniors & $\begin{array}{l}59.3^{* * *} \\
(16.3)\end{array}$ & $\begin{array}{l}32.9^{* * *} \\
(8.7)\end{array}$ & $\begin{array}{l}7.4^{* * *} \\
(2.6)\end{array}$ \\
\hline Net Income & $\begin{array}{r}-1.1 \\
(1.3)\end{array}$ & $\begin{array}{r}0.04 \\
(0.49)\end{array}$ & $\begin{array}{r}-0.1 \\
(0.3)\end{array}$ \\
\hline Cash & $\begin{array}{l}-9.7^{* * *} \\
(2.5)\end{array}$ & $\begin{array}{l}3.7^{* * *} \\
(1.3)\end{array}$ & $\begin{array}{c}0.9^{*} \\
(0.5)\end{array}$ \\
\hline Q & $\begin{array}{l}-2.5^{* * *} \\
(0.3)\end{array}$ & $\begin{array}{l}-0.4^{* * *} \\
(0.1)\end{array}$ & $\begin{array}{l}-0.06^{* *} \\
(0.03)\end{array}$ \\
\hline Debt & $\begin{array}{l}-16.8^{* * *} \\
(2.1)\end{array}$ & $\begin{array}{l}-2.6^{* * *} \\
(0.8)\end{array}$ & $\begin{array}{l}-1.1^{* * *} \\
(0.3)\end{array}$ \\
\hline Volatility & $\begin{array}{c}-131.4^{* * *} \\
(5.0)\end{array}$ & $\begin{array}{l}-6.3^{* * *} \\
(1.9)\end{array}$ & $\begin{array}{l}-6.3^{* * *} \\
(0.5)\end{array}$ \\
\hline Two-year Lagged Return & $\begin{array}{r}-0.05 \\
(0.44)\end{array}$ & $\begin{array}{r}0.32^{*} \\
(0.18)\end{array}$ & $\begin{array}{r}-0.04 \\
(0.04)\end{array}$ \\
\hline Log of Market Value & $\begin{array}{l}9.2^{* * *} \\
(0.5)\end{array}$ & $\begin{array}{l}0.44^{* *} \\
(0.19)\end{array}$ & $\begin{array}{r}0.04 \\
(0.05)\end{array}$ \\
\hline Log of Assets & $\begin{array}{l}-3.0^{* * *} \\
(0.5)\end{array}$ & $\begin{array}{r}-0.04 \\
(0.18)\end{array}$ & $\begin{array}{l}0.11^{* *} \\
(0.05)\end{array}$ \\
\hline Asset Growth & $\begin{array}{l}-4.2^{* * *} \\
(1.2)\end{array}$ & $\begin{array}{r}-0.54 \\
(0.56)\end{array}$ & $\begin{array}{r}-0.35 \\
(0.22)\end{array}$ \\
\hline Age 1-5 & $\begin{array}{l}-16.3^{* * *} \\
(1.4)\end{array}$ & $\begin{array}{r}-0.67 \\
(0.78)\end{array}$ & $\begin{array}{r}-0.17 \\
(0.15)\end{array}$ \\
\hline Age 6-10 & $\begin{array}{l}-18.5^{* * *} \\
(1.1)\end{array}$ & $\begin{array}{l}-1.56^{* *} \\
(0.64)\end{array}$ & $\begin{array}{l}-0.63^{* * *} \\
(0.09)\end{array}$ \\
\hline Age 11-15 & $\begin{array}{l}-14.0^{* * *} \\
(1.2)\end{array}$ & $\begin{array}{r}-1.06 \\
(0.77)\end{array}$ & $\begin{array}{l}-0.64^{* * *} \\
(0.09)\end{array}$ \\
\hline Age 16-20 & $\begin{array}{l}-7.7^{* * *} \\
(1.2)\end{array}$ & $\begin{array}{r}-0.42 \\
(0.82)\end{array}$ & $\begin{array}{l}-0.36^{* * *} \\
(0.11)\end{array}$ \\
\hline $\begin{array}{l}\text { Adjusted } R^{2} \\
\text { Number of Observations }\end{array}$ & $\begin{array}{r}0.528 \\
12,107\end{array}$ & $\begin{array}{l}0.086 \\
6,200\end{array}$ & $\begin{array}{r}0.295 \\
12,107\end{array}$ \\
\hline
\end{tabular}




\section{Table III \\ Repurchases, Corporate Performance, and Local Seniors}

This table presents OLS regression results for pooled regressions for the 1980, 1990, and 2000 cross-sections. Dependent variables are measured one year after the firm- and the county-level controls. Repurchase Yield is the dollar amount of stock repurchases made in year $t+1$ divided by end-of-year $t$ equity market value. Investment refers to capital expenditure in year $t+1$ divided by end-of-year $t$ assets. Net Income refers to net income in year $t+1$ divided by end-of-year $t$ assets. See Table II for a description of the independent variables. Standard errors (shown in parentheses) allow for heteroskedasticity and are clustered by firm. ${ }^{* * *},{ }^{* *},{ }^{*}$ denote significance at the $1 \%, 5 \%$, and $10 \%$ levels, respectively.

\begin{tabular}{|c|c|c|c|c|}
\hline & \multicolumn{2}{|c|}{ Repurchases } & \multicolumn{2}{|c|}{ Corporate Performance } \\
\hline & $\begin{array}{l}(1) \\
\text { Repurchase } \\
\text { Yield }\end{array}$ & $\begin{array}{c}(2) \\
\text { Repurchase Yield } \\
\text { (three-year average) }\end{array}$ & $\begin{array}{c}\text { (3) } \\
\text { Investment }\end{array}$ & $\begin{array}{c}(4) \\
\text { Net } \\
\text { Income }\end{array}$ \\
\hline Local Seniors & $\begin{array}{r}2.17 \\
(1.69)\end{array}$ & $\begin{array}{r}0.57 \\
(1.08)\end{array}$ & $\begin{array}{r}-1.30 \\
(2.47)\end{array}$ & $\begin{array}{r}-6.57 \\
(11.0)\end{array}$ \\
\hline Net Income & $\begin{array}{c}0.39^{* *} \\
(0.20)\end{array}$ & $\begin{array}{c}0.39^{* * *} \\
(0.16)\end{array}$ & $\begin{array}{r}0.03 \\
(0.27)\end{array}$ & \\
\hline Cash & $\begin{array}{l}2.24^{* * *} \\
(0.39)\end{array}$ & $\begin{array}{l}1.46^{* * *} \\
(0.23)\end{array}$ & $\begin{array}{l}-2.74^{* * *} \\
(0.44)\end{array}$ & $\begin{array}{r}-4.90 \\
(3.03)\end{array}$ \\
\hline Q & $\begin{array}{r}-0.04 \\
(0.03)\end{array}$ & $\begin{array}{r}-0.01 \\
(0.02)\end{array}$ & $\begin{array}{l}-0.18^{* \text { **t }} \\
(0.05)\end{array}$ & $\begin{array}{l}-2.04^{\text {*** }} \\
(0.44)\end{array}$ \\
\hline Debt & $\begin{array}{r}-0.40 \\
(0.26)\end{array}$ & $\begin{array}{l}-0.41^{* *} \\
(0.18)\end{array}$ & $\begin{array}{l}1.24^{* * *} \\
(0.37)\end{array}$ & $\begin{array}{r}2.21 \\
(2.20)\end{array}$ \\
\hline Volatility & $\begin{array}{l}-1.31^{*} \\
(0.73)\end{array}$ & $\begin{array}{r}-0.71 \\
(0.49)\end{array}$ & $\begin{array}{r}0.02 \\
(0.96)\end{array}$ & $\begin{array}{l}-115.8^{* * *} \\
(6.81)\end{array}$ \\
\hline Two-year Lagged Return & $\begin{array}{l}0.12^{* *} \\
(0.05)\end{array}$ & $\begin{array}{l}0.066^{* *} \\
(0.033)\end{array}$ & $\begin{array}{l}0.60^{* \star *} \\
(0.08)\end{array}$ & $\begin{array}{l}5.72^{* * *} \\
(0.47)\end{array}$ \\
\hline Log of Market Value & $\begin{array}{l}-0.30^{* * *} \\
(0.08)\end{array}$ & $\begin{array}{l}-0.20^{* * * *} \\
(0.05)\end{array}$ & $\begin{array}{l}1.21^{* * *} \\
(0.08)\end{array}$ & $\begin{array}{l}1.77^{* * *} \\
(0.54)\end{array}$ \\
\hline Log of Assets & $\begin{array}{l}0.32^{* * *} \\
(0.08)\end{array}$ & $\begin{array}{l}0.30^{* * *} \\
(0.05)\end{array}$ & $\begin{array}{l}-1.11^{* * *} \\
(0.09)\end{array}$ & $\begin{array}{r}-0.71 \\
(0.59)\end{array}$ \\
\hline Asset Growth & $\begin{array}{c}-0.38^{*} \\
(0.21)\end{array}$ & $\begin{array}{l}-0.42^{\star \star *} \\
(0.16)\end{array}$ & $\begin{array}{l}1.26^{* * *} \\
(0.26)\end{array}$ & $\begin{array}{r}0.76 \\
(2.28)\end{array}$ \\
\hline $\begin{array}{l}\text { Adjusted R2 } \\
\text { Number of Observations }\end{array}$ & $\begin{array}{r}0.040 \\
10,513\end{array}$ & $\begin{array}{l}0.058 \\
9,020\end{array}$ & $\begin{array}{r}0.379 \\
10,924\end{array}$ & $\begin{array}{r}0.256 \\
12,115\end{array}$ \\
\hline
\end{tabular}




\section{Table IV}

\section{Dividend Payout and Local Seniors, with Growing Counties and Demographic and Economic Controls}

This table presents OLS regression results for firm dividend payout behavior, estimated over the sample of pooled observations from the 1980, 1990, and 2000 cross-sections, with additional considerations. Dependent variables are measured one year after the firmand county-level controls. See Table II for a description of dependent variables and for the independent variables included in the regressions. Columns (1), (4), and (7) replicate Table II. Columns (2), (5), and (8) are based on the same baseline specifications, but the sample is limited to firms that, relative to the preceding census, have experienced population growth in the number of residents in the county who are less than 40 years of age (the "Growing County Sample"). Finally, columns (3), (6), and (9) feature specifications similar to those from columns (1), (4), and (7), respectively, with additional demographic and economic controls. Demographic controls are the logarithm of county population and the educational composition of the county (the fraction of the population having finished college, the fraction of the population having finished high school, and so on). Economic controls are the average of each of the firm-level variables across all firms located in the county, as well as the share of local firms in each industry (two-digit SIC), median house prices in the county, and median income in the county. For clarity, the table provides only the coefficients associated with Local Seniors. Standard errors (shown in parentheses) allow for heteroskedasticity and are clustered by firm. ${ }^{* * *}$, ${ }^{* *}{ }^{*}$ denote significance at the 1 percent, 5 percent, and 10 percent levels, respectively.

\begin{tabular}{|c|c|c|c|c|c|c|c|c|c|}
\hline & \multicolumn{3}{|c|}{ Dividend Payer } & \multicolumn{3}{|c|}{ Dividend Initiation } & \multicolumn{3}{|c|}{ Dividend Yield } \\
\hline & (1) & (2) & (3) & (4) & (5) & (6) & (7) & (8) & (9) \\
\hline Local Seniors & $\begin{array}{l}59.3^{* * *} \\
(16.3)\end{array}$ & $\begin{array}{l}59.1^{* * *} \\
(20.8)\end{array}$ & $\begin{array}{l}35.6^{* *} \\
(18.3)\end{array}$ & $\begin{array}{l}32.9^{* * *} \\
(8.7)\end{array}$ & $\begin{array}{l}26.3^{* * *} \\
(9.8)\end{array}$ & $\begin{array}{l}36.8^{* * *} \\
(10.0)\end{array}$ & $\begin{array}{l}7.4^{* * * *} \\
(2.6)\end{array}$ & $\begin{array}{l}7.4^{* *} \\
(3.8)\end{array}$ & $\begin{array}{l}7.1^{* *} \\
(3.2)\end{array}$ \\
\hline Baseline Regression Controls? & Yes & Yes & Yes & Yes & Yes & Yes & Yes & Yes & Yes \\
\hline Growing County Sample? & No & Yes & No & No & Yes & No & No & Yes & No \\
\hline Demographic Controls? & No & No & Yes & No & No & Yes & No & No & Yes \\
\hline Economic Controls? & No & No & Yes & No & No & Yes & No & No & Yes \\
\hline Adjus & 0.528 & 0.525 & 0.53 & 0.086 & 0.101 & 0.091 & 0.295 & 0.300 & 0.303 \\
\hline Number of Observations & 12,107 & 7,899 & 12,071 & 6,200 & 4,409 & 6,177 & 12,107 & 7,899 & 12,071 \\
\hline
\end{tabular}




\section{Table V \\ Dividend Payout and Local Seniors, Interactions with Small Firms, High Local-bias Counties, Banking Industry, and Number of Firms in County}

This table presents OLS regression results for dividend payout behavior, estimated over the sample of pooled observations from the 1980, 1990, and 2000 cross-sections. The dependent variable Dividend Payer is measured one year after the firm- and the county-level controls. See Table II for a description of the Dividend Payer dependent variable and for the independent variables included in the regressions. Column (1) reports the baseline regression coefficient on the Local Seniors variable from Table II. In columns (2) through (4), the specification from Table II is augmented with interactions using various indicator variables. The first such indicator variable is Small Firm; it is equal to one for firms with below-median market capitalization in a given cross-section, and zero otherwise. The second indicator variable, featured in column (3), is High Local-bias County; it is equal to one if the firm is headquartered in a county in which the extent of local bias among the non-senior local retail investors from the brokerage data is above the sample median, and zero otherwise. The third indicator variable, featured in column (4), is Bank; it is equal to one for firms in the banking industry (two-digit SIC equal to 60), and zero otherwise. For clarity, in columns (2) through (4) the table provides only the coefficients associated with the Local Seniors variable and, if applicable, its interaction with the respective indicator variables. Moreover, columns (2) through (4) also feature the total effect of Local Seniors for small firms (column (2)), for firms located in high-local bias counties (column (3)), and for firms in the banking industry (column (4)). In column (5), the specification is similar to that from Table II, with the addition of the Inverse Number of Firms, measured for each firm as the inverse of the number of the firms headquartered in the same county (including the firm itself), as well as the interaction between Local Seniors and Inverse Number of Firms. For clarity, in column (5) the table provides only the coefficients associated with Local Seniors, Inverse Number of Firms, and their interaction. Standard errors (shown in parentheses) allow for heteroskedasticity and are clustered by firm. ${ }^{* * *},{ }^{* *},{ }^{*}$ denote significance at the $1 \%, 5 \%$, and $10 \%$ levels, respectively. 


\section{Table V}

Dividend Payout and Local Seniors, Interactions with Small Firms, High Local-bias Counties, Banking Industry, and Number of Firms in County (continued)

\begin{tabular}{|c|c|c|c|c|c|}
\hline & $(1)$ & $(2)$ & (3) & $(4)$ & $(5)$ \\
\hline Local Seniors & $\begin{array}{l}59.3^{* * *} \\
(16.3)\end{array}$ & $\begin{array}{r}7.6 \\
(24.0)\end{array}$ & $\begin{array}{r}24.1 \\
(21.9)\end{array}$ & $\begin{array}{l}52.2^{* * *} \\
(17.0)\end{array}$ & $\begin{array}{r}23.5 \\
(18.6)\end{array}$ \\
\hline Local Seniors $x$ Small Firm & & $\begin{array}{l}92.2^{* * *} \\
(30.5)\end{array}$ & & & \\
\hline Total effect for small firms & & $\begin{array}{l}99.8^{* * *} \\
(20.2)\end{array}$ & & & \\
\hline Local Seniors x High Local-Bias County & & & $\begin{array}{l}119.9^{* * *} \\
(46.3)\end{array}$ & & \\
\hline Total effect for firms in high local-bias counties & & & $\begin{array}{l}144.0^{* * *} \\
(40.8)\end{array}$ & & \\
\hline Local Seniors x Bank & & & & $\begin{array}{l}82.3^{* *} \\
(40.1)\end{array}$ & \\
\hline Total effect for banks & & & & $\begin{array}{l}134.5^{* * *} \\
(38.6)\end{array}$ & \\
\hline Inverse of Number of Firms & & & & & $\begin{array}{l}-2.1 \\
(6.7)\end{array}$ \\
\hline Local Seniors $x$ Inverse of Number of Firms & & & & & $\begin{array}{l}105.7^{\text {** }} \\
(49.4)\end{array}$ \\
\hline $\begin{array}{l}\text { Adjusted } \mathrm{R}^{2} \\
\text { Number of Observations }\end{array}$ & $\begin{array}{c}0.528 \\
12,107 \\
\end{array}$ & $\begin{array}{c}0.560 \\
12,107 \\
\end{array}$ & $\begin{array}{c}0.536 \\
11,436 \\
\end{array}$ & $\begin{array}{r}0.529 \\
12,107 \\
\end{array}$ & $\begin{array}{c}0.530 \\
12,107 \\
\end{array}$ \\
\hline
\end{tabular}




\section{Table VI \\ Relating Changes in Dividend Payer Status to Changes in Local Seniors, Analysis of Movers}

This table presents results of OLS regressions that relate changes in dividend payer status to changes in the fraction of local seniors, as well as changes in the other independent variables described in Table II. The results are presented in five panels, corresponding to postmove horizons of one to five years. In each panel, column (1) focuses on the sample of firms, obtained from Compact Disclosure, that moved their corporate headquarters to a different state in the period from 1997 to 2000 and that have sufficient data pre- and post-move to conduct our analyses. For this sample, regressions relate pre-move to post-move changes in dividend payer status over various postmove horizons with changes in the fraction of local seniors across the post- and pre-move communities, as well as in the other independent variables. The second column in each panel reports the results of these change regressions for the complete sample of firms in existence during the pre-and post-move years of the 1997 to 2000 sample of movers. The only additional independent variable in columns (2) is the indicator variable Firm Moved; it is equal to one if the firm's headquarters had moved, and zero otherwise. For the purposes of the analyses presented in this table, we incorporate observations in off-Census years that occurred both before and after the move. For such observations, we use linear interpolations of Census figures from the 1990 and 2000 Censuses (and extrapolations for years after 2000). Standard errors (shown in parentheses) allow for heteroskedasticity and are clustered by firm. ${ }^{* * *},{ }^{* *},{ }^{*}$ denote significance at the $1 \%, 5 \%$, and $10 \%$ levels, respectively.

\begin{tabular}{|c|c|c|c|c|c|c|c|c|c|c|}
\hline \multirow[t]{2}{*}{$\begin{array}{l}\text { Change in } \\
\text { Dividend payer Status }\end{array}$} & \multicolumn{2}{|c|}{$\begin{array}{c}\text { Panel A: } \\
1 \text { Year Post-move } \\
\text { Relative to } \\
1 \text { Year Pre-move }\end{array}$} & \multicolumn{2}{|c|}{$\begin{array}{c}\text { Panel B: } \\
2 \text { Years Post-move } \\
\text { Relative to } \\
1 \text { Year Pre-move }\end{array}$} & \multicolumn{2}{|c|}{$\begin{array}{c}\text { Panel C: } \\
\text { 3 Years Post-move } \\
\text { Relative to } \\
1 \text { Year Pre-move }\end{array}$} & \multicolumn{2}{|c|}{$\begin{array}{c}\text { Panel D: } \\
4 \text { Years Post-move } \\
\text { Relative to } \\
1 \text { Year Pre-move }\end{array}$} & \multicolumn{2}{|c|}{$\begin{array}{c}\text { Panel E: } \\
5 \text { Years Post-move } \\
\text { Relative to } \\
1 \text { Year Pre-move }\end{array}$} \\
\hline & $\begin{array}{c}(1) \\
\text { Movers } \\
\text { Only }\end{array}$ & $\begin{array}{c}(2) \\
\text { All } \\
\text { Firms } \\
\end{array}$ & $\begin{array}{c}(1) \\
\text { Movers } \\
\text { Only }\end{array}$ & $\begin{array}{c}(2) \\
\text { All } \\
\text { Firms }\end{array}$ & $\begin{array}{c}(1) \\
\text { Movers } \\
\text { Only }\end{array}$ & $\begin{array}{c}(2) \\
\text { All } \\
\text { Firms } \\
\end{array}$ & $\begin{array}{c}(1) \\
\text { Movers } \\
\text { Only }\end{array}$ & $\begin{array}{c}\text { (2) } \\
\text { All } \\
\text { Firms }\end{array}$ & $\begin{array}{c}(1) \\
\text { Movers } \\
\text { Only }\end{array}$ & $\begin{array}{c}(2) \\
\text { All } \\
\text { Firms }\end{array}$ \\
\hline Seniors & $\begin{array}{l}\mathbf{1 1 1 . 2}^{* *} \\
(49.8)\end{array}$ & $\begin{array}{c}\text { 98.1 }^{* *} \\
(41.1)\end{array}$ & $\begin{array}{l}\mathbf{1 7 0 . 4 ^ { * * }} \\
(75.7)\end{array}$ & $\begin{array}{l}163.2^{* *} \\
(69.6)\end{array}$ & $\begin{array}{l}\text { 190.9** }^{* *} \\
(88.4)\end{array}$ & $\begin{array}{l}\mathbf{1 8 7 . 1}^{* *} \\
(82.4)\end{array}$ & $\begin{array}{c}240.6^{* *} \\
(108.7)\end{array}$ & $\begin{array}{l}213.4^{* *} \\
(89.1)\end{array}$ & $\begin{array}{l}\text { 343.2*** } \\
(119.3)\end{array}$ & $\begin{array}{l}\mathbf{3 0 0 . 9}^{* * *} \\
(114.3)\end{array}$ \\
\hline Firm & & $\begin{array}{r}1.0 \\
(1.4)\end{array}$ & & $\begin{array}{r}-0.2 \\
(1.6)\end{array}$ & & $\begin{array}{l}-0.7 \\
(2.2)\end{array}$ & & $\begin{array}{l}-0.8 \\
(2.6)\end{array}$ & & $\begin{array}{r}0.8 \\
(3.6)\end{array}$ \\
\hline iluj & 0.143 & $.0 \angle T$ & 0.202 & 0.00 & 0.209 & 0.000 & 0.234 & 0.000 & 0.396 & 0.070 \\
\hline Number of Observations & 145 & 14,338 & 114 & 12,829 & 99 & 11,693 & 91 & 10,825 & 82 & 9,748 \\
\hline
\end{tabular}




\section{Table VII \\ Ex-Dividend Day Returns}

This table presents results of estimating OLS regressions that relate the price drop on the ex-dividend date to Local Seniors and other covariates. The estimation is carried out over the sample of stock returns surrounding ex-dividend days in the period from 1992 to 2007. The dependent variable is the relative price drop - the negative of the price change from the close of the last cum-dividend day to the open of the ex-dividend day divided by the closing price of the last cum-dividend day. The first column relates the price drop to the amount of the dividend scaled by the closing price ( $\operatorname{Div}_{i, t} / P_{i, t-1}^{\text {close }}$, abbreviated in the table as $\operatorname{Div} / P$ for readability). In the second column, Div $/ P$ is interacted with the indicator variable Small Firm (defined as in Table V) to allow for differential effects across large and small firms. In columns (3) and (4), two county-level variables are added to the specification: Local Seniors (the fraction of residents who are 65 years old or older in the county in which a firm is headquartered, as reported by the U.S. Census Bureau) and Median Income (measured at the county level; this geographically-based measure of income is intended to capture local taxrelated motivations more directly). The third column includes Div/P, Local Seniors, Median Income, as well as interactions between Div/P and Local Seniors and Median Income, respectively. The fourth column further allows for interactions of all independent variables featured in the third column with the indicator variable Small Firm. Local Seniors and Median Income in off-census years are estimated by linear interpolation (or extrapolation) of the figures from the Census years. In light of the primary interest in how community characteristics affect the relation between the ex-dividend day price drop and the amount of the dividend, the coefficients associated with Local Seniors and Median Income, and their interactions with the Small Firm indicator variable are suppressed from the table for readability. These coefficients are reported in the text of Section III.B. Standard errors (shown in parentheses) allow for heteroskedasticity and are clustered by firm. ${ }^{* * *},{ }^{* *},{ }^{*}$ denote significance at the $1 \%, 5 \%$, and $10 \%$ levels, respectively.

\begin{tabular}{|c|c|c|c|c|}
\hline & (1) & $(2)$ & (3) & (4) \\
\hline $\mathrm{Div} / \mathrm{P}$ & $\begin{array}{l}0.73^{* * *} \\
(0.05)\end{array}$ & $\begin{array}{l}0.86^{* * *} \\
(0.02)\end{array}$ & $\begin{array}{r}0.36 \\
(0.23)\end{array}$ & $\begin{array}{l}0.92^{* * *} \\
(0.08)\end{array}$ \\
\hline$($ Div /P) $x$ Small Firm & & $\begin{array}{l}-0.26^{* * *} \\
(0.09)\end{array}$ & & $\begin{array}{l}-0.89^{* * *} \\
(0.34)\end{array}$ \\
\hline Total effect of Div/P for small firms & & \begin{tabular}{|c|}
$0.60^{* * * *}$ \\
$(0.09)$
\end{tabular} & & $\begin{array}{r}0.04 \\
(0.33)\end{array}$ \\
\hline$(\operatorname{Div} / \mathrm{P}) \times$ Local Seniors & & & $\begin{array}{l}3.0^{*} \\
(1.7)\end{array}$ & $\begin{array}{r}-0.19 \\
(0.54)\end{array}$ \\
\hline$(\operatorname{Div} / \mathrm{P}) \times$ Local Seniors $\times$ Small Firm & & & & $\begin{array}{l}4.9^{*} \\
(2.6)\end{array}$ \\
\hline Total effect of (Div/P) $\times$ LocalSeniors for small firms & & & & $\begin{array}{c}4.7^{*} \\
(2.5)\end{array}$ \\
\hline$(\operatorname{Div} / \mathrm{P}) \times$ Median Income & & & $\begin{array}{l}-0.08^{* *} \\
(0.03)\end{array}$ & $\begin{array}{r}-0.01 \\
(0.01)\end{array}$ \\
\hline$($ Div $/ P) \times$ Median Income $x$ Small Firm & & & & $\begin{array}{l}-0.10^{*} \\
(0.06)\end{array}$ \\
\hline Total effect of (Div/P) x Med. Income for small firms & & & & \begin{tabular}{|l|}
$-0.11^{* *}$ \\
$(0.06)$ \\
\end{tabular} \\
\hline Adjusted R-squ & 0.196 & 0.201 & 0.198 & 0.205 \\
\hline Number of Observations & 116,933 & 116,933 & 116,370 & 116,370 \\
\hline
\end{tabular}




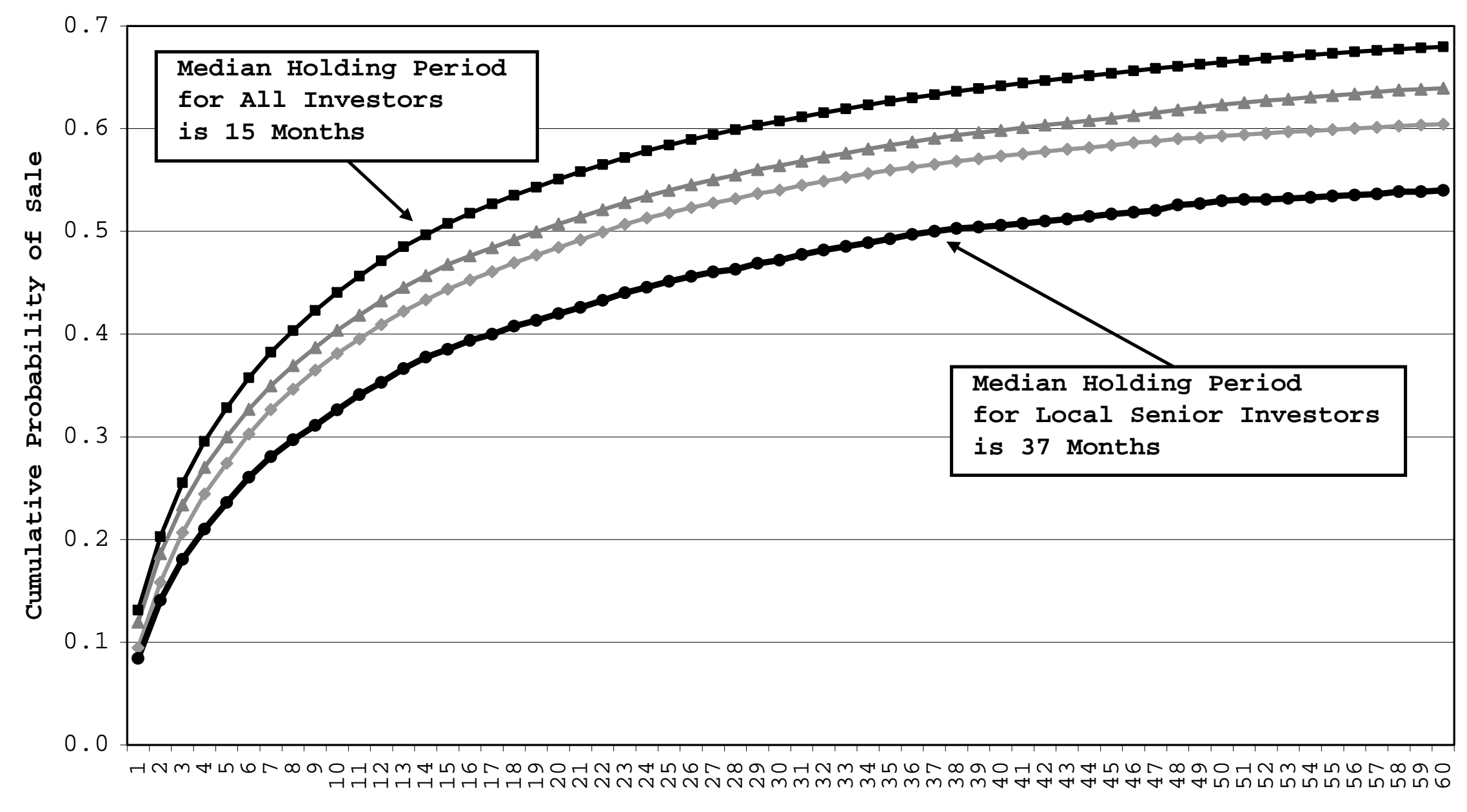

Months Since Purchase

$\rightarrow$ All Investors $\rightarrow$ Local Investors $\leadsto$ Senior Investors $\rightarrow$ Local Senior Investors 
Figure 1. Hazard rates of sale and median holding periods. This figure plots cumulative probabilities of the sale of stocks purchased by slightly more than 30,000 individual investors who invested through a large discount broker in the period from 1991 to 1996. The first step is the computation of the nonparametric hazard rates for purchases made by 1) all investors for whom the data record their location and age, 2) local investors (whose household is within 250 miles of the location of the company headquarters), 3) senior investors (individuals 65 years of age or older), and 4) local senior investors. The second step cumulates the hazard rates into the cumulative probability of sale as a function of the number of months since purchase. 


\section{FOOTNOTES}

${ }^{1}$ We follow Graham and Kumar (2006) in our definition of senior investors as individuals 65 years of age or older.

${ }^{2}$ Local senior investors likely are nontrivial owners of shares in corporations (particularly smaller firms, more likely to face geographically segmented markets). A compilation of data from multiple sources enables a crude estimate. At the middle of our sample period, direct stock ownership by households in the U.S. (not including indirect stock ownership though mutual funds) was roughly 55\% (see Flow of Funds Accounts from the Federal Reserve Board). According to the 1992 Survey of Consumer Finances (SCF), senior households accounted for roughly two-fifths of total direct household stock ownership. Authors' calculations using the database of brokerage accounts for retail investors over the period from 1991 to 1996 (see Section I for a description of that data set) suggest that about one-quarter of senior stock holdings are in local companies. Taking these numbers together leads to a rough approximation that local senior direct stock ownership comprises about $5 \%$ to $6 \%$ of total stock ownership and about $10 \%$ of total household stock ownership (i.e., non-institutional ownership).

3 In each census-year cross-section, the standard deviation of the fraction of seniors is around 3 percentage points, the interquartile range is around 3.5 percentage points, and the difference between the maximum and minimum fraction of seniors across all U.S. counties is 30 percentage points.

${ }^{4}$ For a detailed description of the data set, see Barber and Odean (2000).

${ }^{5}$ We thank Jun-Koo Kang and Jin-Mo Kim for providing us with the data concerning headquarter moves.

${ }^{6}$ For robustness, we also have estimated these regressions in logit, probit, and tobit frameworks and have obtained very similar results, with statistical significance of the Local Seniors variable at the $1 \%$ level in all specifications. The coefficient estimates obtained from these specifications are reported in the Internet Appendix.

${ }^{7}$ As a further measure of the relative importance of various independent variables in explaining dividend policy, we calculated the contribution of these variables to the $\mathrm{R}^{2}$ of the Dividend Payer, Dividend Initiation, and Dividend Yield regressions. These results are displayed in the Internet Appendix.

8 Besides analyzing dividend payer status, dividend initiations, and the dividend yield, we also studied the determinants of dividend omissions, that is, whether companies, conditional on paying dividends in year $t$, stopped paying them next year, in year $t+1$. The results are displayed in the Internet Appendix. Dividend omissions were concentrated among companies that clearly were in financial distress, with low profitability, high stock return volatility, and low past stock returns. Brav et al. (2005, p. 521) report in 
their survey concerning payout policy that executives "do not cut dividends except in extreme circumstances" and that there is a "big market penalty for reducing and omitting [dividends]." Perhaps, in light of this observation, it is not surprising that Local Seniors does not have a strong or statistically significant effect on dividend omissions - in these dire circumstances, when company survival may be at stake, the preferences of local shareholders likely are not of first-order importance to managers.

9 There are approximately twice as many observations associated with corporations headquartered in counties with positive growth of young people since the last census than there are observations in counties with negative growth of young people.

${ }^{10}$ We thank the Co-Editor, John Graham, for this suggestion.

${ }^{11}$ In constructing this measure, we consider non-senior household portfolios (specifically, those held by investors younger than 40 years of age) to avoid endogeneity issues (that is, that the local bias of seniors might be strong in those locations in which firms' dividend policies correspond to local seniors' preferences). The identifying assumption is that non-seniors' local bias captures some aspect (other than dividend preference) that affects the local bias of seniors as well, such as exposure to the same business news or advertising.

12 Calculations are based on the 2001 Survey of Consumer Finances (SCF), using the SCF-provided sampling weights to calculate estimates for the U.S. population as a whole, and the U.S. Census Bureau figures.

${ }^{13}$ We thank Jun-Koo Kang and Min-Jo Kim for providing us these data. Their original data have 418 moves across states over the period from 1997 to 2000, as recorded by Compact Disclosure. Of these 418 potential firm moves, 227 companies can be linked with Compustat and have data on dividend policy both one year before and one year after the move. Further requiring data on all the changes in the control variables over the pre-move to post-move period results in the final sample of 145 company moves displayed in column (1) of Table VI, Panel A.

14 Aside from the change in dividend-payer status and the change in Local Seniors across the two communities, regressions include changes in all of the firm-level covariates displayed in Table II (Net Income, Cash, Q, Debt, Volatility, Two-year Lagged Return, Log of Market Value, Log of Assets, and Asset Growth), as well as the age-group indicator variables at the time of the move.

${ }^{15}$ Coefficients associated with changes in the firm-level variables in these change regressions line up as expected. See the Internet Appendix for the coefficient estimates associated with the other independent variables. 
16 Corporations generally are known to care, at least to some extent, about retail investors. According to Brav et al. (2005), executives believe that attracting retail investors to purchase their stock is an important motivation behind company dividend policy.

${ }^{17}$ We thank Denis Gromb for suggesting this approach.

18 This methodology avoids normalizing by any small quantity (such as the dividend amount) and, therefore, is more statistically robust.

19 The Elton and Gruber (1970) estimation corresponds to estimating this regression and weighting observations by the inverse of their dividend yield (that is, putting the most weight on observations pertaining to stocks with the lowest yields). Thus, our methodology generalizes the original approach from Elton and Gruber (1970).

20 The coefficient associated with Local Seniors in the specification presented in column (3) is $0.004(\mathrm{SE}=$ $0.005)$ and the coefficient associated with Median Income is $0.009(\mathrm{SE}=0.004)$.

${ }^{21}$ Once again for readability, in Table VII we do not report the coefficients associated with Local Seniors and Median Income, nor do we report their interactions with Small Firm, the small-firm indicator variable. The coefficient associated with Local Seniors in the specification presented in column (4) is $-0.001(\mathrm{SE}=$ 0.003 ) and the interaction of Local Seniors and Small Firm is -0.001 (SE = 0.011). The coefficient associated with Median Income is $0.001(\mathrm{SE}=0.001)$ and the interaction of Median Income with Small Firm is 0.016 (SE $=0.070)$. 


\section{Internet Appendix to "Local Dividend Clienteles"*}

\section{Table IA.I \\ Dividend Payout and Local Seniors}

This table presents regression results for firm dividend payout behavior, estimated over the sample of pooled observations from the 1980, 1990, and 2000 cross-sections. The regressions and all the variables mirror those from Table II of the main article (see Table II of the main article for further details). Instead of OLS (featured in Table II of the main article), in this table a probit model is employed for the regression results reported in the first and third columns, a logit specification is employed for the results reported in the second and fourth columns, and a tobit model is employed for the regression results reported in the fifth column. Standard errors (shown in parentheses) allow for heteroskedasticity and are clustered by firm. ${ }^{* * *},{ }^{* *},{ }^{*}$ denote significance at the $1 \%, 5 \%$, and $10 \%$ levels, respectively.

* Citation format: Becker, Bo, Zoran Ivković, and Scott Weisbenner, 2010, Internet Appendix to "Local Dividend Clienteles," Journal of Finance 65, pppp - pppp, http://www.afajof.org/IA/2010.asp. Please note: Wiley-Blackwell is not responsible for the content or functionality of any supporting information supplied by the authors. Any queries (other than missing material) should be directed to the authors of the article. 
Table IA.I

Dividend Payout and Local Seniors (continued)

\begin{tabular}{|c|c|c|c|c|c|}
\hline & \multicolumn{2}{|c|}{$\begin{array}{l}\text { Dividend } \\
\text { Payer }\end{array}$} & \multicolumn{2}{|c|}{$\begin{array}{l}\text { Dividend } \\
\text { Initiation }\end{array}$} & \multirow{2}{*}{$\begin{array}{c}\text { Dividend } \\
\text { Yield } \\
\text { Tobit } \\
\end{array}$} \\
\hline & Probit & Logit & Probit & Logit & \\
\hline Local Seniors & $\begin{array}{c}2.7^{* * *} \\
(0.8)\end{array}$ & $\begin{array}{l}4.1^{* * *} \\
(1.4)\end{array}$ & $\begin{array}{c}9.2^{\text {**k }} \\
(2.5)\end{array}$ & $\begin{array}{l}16.2^{* * *} \\
(4.7)\end{array}$ & $\begin{array}{l}13.4^{* * *} \\
(2.5)\end{array}$ \\
\hline Net Income & $\begin{array}{l}3.1^{* * *} \\
(0.9)\end{array}$ & $\begin{array}{l}7.8^{\star * * *} \\
(0.9)\end{array}$ & $\begin{array}{c}1.1^{*} \\
(0.6)\end{array}$ & $\begin{array}{r}0.91 \\
(0.74)\end{array}$ & $\begin{array}{l}6.3^{* * * *} \\
(0.8)\end{array}$ \\
\hline Cash & $\begin{array}{c}-0.45^{\text {*** }} \\
(0.18)\end{array}$ & $\begin{array}{l}-1.0^{* * *} \\
(0.3)\end{array}$ & $\begin{array}{l}1.2^{* * *} \\
(0.3)\end{array}$ & $\begin{array}{l}2.1^{* * *} \\
(0.6)\end{array}$ & $\begin{array}{c}1.2^{* *} \\
(0.5)\end{array}$ \\
\hline Q & $\begin{array}{l}-0.16^{\text {*** }} \\
(0.03)\end{array}$ & $\begin{array}{l}-0.31^{* * *} \\
(0.05)\end{array}$ & $\begin{array}{l}-0.60^{\text {**k }} \\
(0.10)\end{array}$ & $\begin{array}{c}-0.39^{* * *} \\
(0.09)\end{array}$ & $\begin{array}{l}-0.35^{\text {*** }} \\
(0.06)\end{array}$ \\
\hline Debt & $\begin{array}{l}-0.68^{* \star *} \\
(0.13)\end{array}$ & $\begin{array}{l}-1.0^{* * *} \\
(0.2)\end{array}$ & $\begin{array}{c}-0.89^{* *} \\
(0.37)\end{array}$ & $\begin{array}{l}-1.4^{* *} \\
(0.7)\end{array}$ & $\begin{array}{l}-2.4^{* * *} \\
(0.4)\end{array}$ \\
\hline Volatility & $\begin{array}{c}-10.3^{* * *} \\
(0.6)\end{array}$ & $\begin{array}{l}-20.0^{* * *} \\
(1.0)\end{array}$ & $\begin{array}{l}-2.3^{* * *} \\
(0.8)\end{array}$ & $\begin{array}{l}-4.3^{* * *} \\
(1.6)\end{array}$ & $\begin{array}{l}-37.6^{* * *} \\
(1.4)\end{array}$ \\
\hline Two-year Lagged Return & $\begin{array}{r}0.02 \\
(0.03)\end{array}$ & $\begin{array}{r}0.01 \\
(0.05)\end{array}$ & $\begin{array}{c}0.14^{* * *} \\
(0.05)\end{array}$ & $\begin{array}{r}0.14 \\
(0.10)\end{array}$ & $\begin{array}{c}0.15^{*} \\
(0.09)\end{array}$ \\
\hline Log of Market Value & $\begin{array}{c}0.36^{* * *} \\
(0.04)\end{array}$ & $\begin{array}{c}0.61^{* * *} \\
(0.06)\end{array}$ & $\begin{array}{c}0.38^{* * *} \\
(0.09)\end{array}$ & $\begin{array}{c}0.39^{* * *} \\
(0.14)\end{array}$ & $\begin{array}{l}0.31^{\text {*** }} \\
(0.10)\end{array}$ \\
\hline Log of Assets & $\begin{array}{c}-0.07^{*} \\
(0.04)\end{array}$ & $\begin{array}{r}-0.08 \\
(0.07)\end{array}$ & $\begin{array}{c}-0.18^{* *} \\
(0.09)\end{array}$ & $\begin{array}{c}-0.09^{* *} \\
(0.13)\end{array}$ & $\begin{array}{c}0.19^{*} \\
(0.10)\end{array}$ \\
\hline Asset Growth & $\begin{array}{l}-0.43^{\text {*** }} \\
(0.10)\end{array}$ & $\begin{array}{l}-0.73^{\text {t*** }} \\
(0.19)\end{array}$ & $\begin{array}{r}-0.21 \\
(0.24)\end{array}$ & $\begin{array}{r}-0.43 \\
(0.52)\end{array}$ & $\begin{array}{l}-2.2^{* \star *} \\
(0.3)\end{array}$ \\
\hline Age 1-5 & $\begin{array}{l}-0.59^{* * *} \\
(0.07)\end{array}$ & $\begin{array}{l}-1.08^{* * *} \\
(0.12)\end{array}$ & $\begin{array}{r}-0.03 \\
(0.18)\end{array}$ & $\begin{array}{r}-0.11 \\
(0.34)\end{array}$ & $\begin{array}{l}-0.51^{\text {** }} \\
(0.22)\end{array}$ \\
\hline Age 6-10 & $\begin{array}{l}-0.69^{\text {*** }} \\
(0.05)\end{array}$ & $\begin{array}{l}-1.21^{* * *} \\
(0.10)\end{array}$ & $\begin{array}{l}-0.43^{\text {*** }} \\
(0.16)\end{array}$ & $\begin{array}{c}-0.63^{\text {** }} \\
(0.30)\end{array}$ & $\begin{array}{l}-1.56^{\text {*** }} \\
(0.17)\end{array}$ \\
\hline Age 11-15 & $\begin{array}{l}-0.53^{\text {*** }} \\
(0.06)\end{array}$ & $\begin{array}{l}-0.95^{\text {} \star \star} \\
(0.11)\end{array}$ & $\begin{array}{c}-0.35^{*} \\
(0.19)\end{array}$ & $\begin{array}{r}-0.50 \\
(0.36)\end{array}$ & $\begin{array}{l}-1.19^{* * *} \\
(0.20)\end{array}$ \\
\hline Age 16-20 & $\begin{array}{l}-0.25^{\text {*** }} \\
(0.06)\end{array}$ & $\begin{array}{l}-0.47^{\text {**** }} \\
(0.10)\end{array}$ & $\begin{array}{r}-0.10 \\
(0.19)\end{array}$ & $\begin{array}{r}-0.19 \\
(0.37)\end{array}$ & $\begin{array}{l}-0.46^{* *} \\
(0.18)\end{array}$ \\
\hline Pseudo $\mathrm{R}^{2}$ & 0.558 & 0.566 & 0.321 & 0.124 & 0.161 \\
\hline Number of Observations & 12,107 & 12,107 & 6,200 & 6,200 & 12,107 \\
\hline
\end{tabular}




\section{Table IA.II}

\section{Economic Magnitudes of Effects of Local Seniors and Various Firm-specific Controls on Dividend Policy}

This table is based upon the regression coefficients reported in Table II of the main article. It presents the effects of a one-standard deviation increase in a given independent variable on firm dividend policy. Each panel in this table, pertaining to one dividend payout variable, corresponds to a column in Table II of the main article. The first column of this table replicates the coefficients and significance levels of Local Seniors and key firm-level independent variables. The second column features the standard deviations of the independent variables in the sample. The third column presents the effects of a one-standard deviation increase of the independent variable on firm dividend policy (expressed in percentage points). Finally, the fourth column presents the ratio of that effect to the sample average of the respective dividend policy variable (expressed in percentage points). ${ }^{* * *},{ }^{* *},{ }^{*}$ denote significance at the $1 \%, 5 \%$, and $10 \%$ levels, respectively.

\begin{tabular}{|c|c|c|c|c|}
\hline \multicolumn{5}{|c|}{ Panel A: Dividend Payer (sample average $=47.4$ ) } \\
\hline & $\begin{array}{l}\text { Regression } \\
\text { Coefficient }\end{array}$ & $\begin{array}{l}\text { Std. Dev of } \\
\text { Variable }\end{array}$ & $\begin{array}{l}\text { 1-Std. Dev } \\
\text { Effect }\end{array}$ & $\begin{array}{c}\text { 1-SD Effect / } \\
\text { Avg. of Div. Payer }\end{array}$ \\
\hline Local Seniors & $59.3^{* * *}$ & 0.031 & 1.8 & $3.9 \%$ \\
\hline Cash & $-9.7^{* * *}$ & 0.17 & -1.6 & $-3.5 \%$ \\
\hline $\mathrm{Q}$ & $-2.5^{\text {*** }}$ & 1.9 & -4.7 & $-10.0 \%$ \\
\hline Debt & $-16.8^{* * *}$ & 0.19 & -3.2 & $-6.7 \%$ \\
\hline Volatility & $-131.4^{* * *}$ & 0.09 & -11.8 & $-24.9 \%$ \\
\hline Two-Year Lagged Return & -0.05 & 1.08 & -0.1 & $-0.1 \%$ \\
\hline Log of Market Value & $9.2^{* * *}$ & 2.3 & 21.2 & $44.6 \%$ \\
\hline \multicolumn{5}{|c|}{ Panel B: Dividend Initiation (sample average $=2.0$ ) } \\
\hline & $\begin{array}{l}\text { Regression } \\
\text { Coefficient }\end{array}$ & $\begin{array}{l}\text { Std. Dev of } \\
\text { Variable }\end{array}$ & $\begin{array}{l}\text { 1-Std. Dev } \\
\text { Effect }\end{array}$ & $\begin{array}{c}\text { 1-SD Effect / } \\
\text { Avg. of Div. Payer }\end{array}$ \\
\hline Local Seniors & $32.9^{* * *}$ & 0.031 & 1.0 & $51.0 \%$ \\
\hline Cash & $3.7^{* * *}$ & 0.17 & 0.6 & $31.5 \%$ \\
\hline $\mathrm{Q}$ & $-0.4^{* * *}$ & 1.9 & -0.8 & $-38.0 \%$ \\
\hline Debt & $-2.6^{* * *}$ & 0.19 & -0.5 & $-24.7 \%$ \\
\hline Volatility & $-6.3^{* * *}$ & 0.09 & -0.6 & $-28.4 \%$ \\
\hline Two-Year Lagged Return & $0.32^{*}$ & 1.08 & 0.4 & $17.3 \%$ \\
\hline Log of Market Value & $0.44^{* *}$ & 2.3 & 1.0 & $50.6 \%$ \\
\hline \multicolumn{5}{|c|}{ Panel C: Dividend Yield (sample average $=1.9$ ) } \\
\hline & $\begin{array}{l}\text { Regression } \\
\text { Coefficient }\end{array}$ & $\begin{array}{l}\text { Std. Dev of } \\
\text { Variable }\end{array}$ & $\begin{array}{l}\text { 1-Std. Dev } \\
\text { Effect }\end{array}$ & $\begin{array}{c}\text { 1-SD Effect / } \\
\text { Avg. of Div. Payer }\end{array}$ \\
\hline Local Seniors & $7.4^{* * *}$ & 0.031 & 0.23 & $12.1 \%$ \\
\hline Cash & $0.9^{*}$ & 0.17 & 0.15 & $8.1 \%$ \\
\hline Q & $-0.06^{* *}$ & 1.9 & -0.11 & $-6.0 \%$ \\
\hline Debt & $-1.1^{* * *}$ & 0.19 & -0.21 & $-11.0 \%$ \\
\hline Volatility & $-6.3^{* * *}$ & 0.09 & -0.57 & $-29.8 \%$ \\
\hline Two-Year Lagged Return & -0.04 & 1.08 & -0.04 & $-2.3 \%$ \\
\hline Log of Market Value & 0.04 & 2.3 & 0.09 & $4.8 \%$ \\
\hline
\end{tabular}




\section{Table IA.III}

\section{Reduction in $\mathbf{R}^{2}$ When Omitting a Variable}

This table is based upon the regressions reported in Table II of the main article. It presents the effects of omitting an independent variable on the regression $\mathrm{R}^{2}$ for several independent variables. Each column in this table corresponds to its respective column in Table II of the main article. The first row of each column replicates the adjusted $\mathrm{R}^{2}$ for the full regression, as presented in Table II of the main article. Subsequent rows present, for several independent variables, the reduction of that adjusted $\mathrm{R}^{2}$ that results from estimating the regression with the corresponding independent variable omitted.

\begin{tabular}{lrrr}
\hline & Dividend Payer & Dividend Initiation & Dividend Yield \\
\hline Adjusted R for & $52.8 \%$ & $8.6 \%$ & $29.5 \%$ \\
full specification & & & \\
& & & \\
Reduction of Adjusted R2 & & & \\
when variable is omitted & $0.1 \%$ & $0.2 \%$ & $0.2 \%$ \\
\hline Local Seniors & $0 \%$ & $0 \%$ & $0 \%$ \\
Net Income & $0.1 \%$ & $0.2 \%$ & $0.1 \%$ \\
Cash & $0.4 \%$ & $0.2 \%$ & $0 \%$ \\
Q & $0.3 \%$ & $0.1 \%$ & $0.2 \%$ \\
Debt & $2.8 \%$ & $0.1 \%$ & $0.1 \%$ \\
Volatility & $0 \%$ & $0 \%$ & $0 \%$ \\
Two-Year Lagged Return & $1.6 \%$ & $0 \%$ & $0 \%$ \\
Log of Market Value & $1.6 \%$ & $0.1 \%$ & $0.4 \%$ \\
Age variables & & & \\
\hline
\end{tabular}


Table IA.IV

\section{Dividend Omissions and Local Seniors}

This table presents regression results for the likelihood that a firms stops paying dividends, estimated over the sample of pooled observations from the 1980, 1990, and 2000 cross-sections. The dependent variable, Dividend Omission, is measured one year after the firm-level controls (i.e., in 1981, 1991, and 2001, respectively). It is an indicator variable, defined for firms that paid dividends during year $t$, equal to zero for the firms that remain payers in year $t+1$, and 100 for firms that do not pay dividends in year $t+1$. The control variables mirror those from Table II of the main article and Table IA.I (see Table II of the main article for further details). Results from an OLS regression are displayed in the first column, with regression coefficients from probit and logit models displayed in the second and third columns, respectively. Standard errors (shown in parentheses) allow for heteroskedasticity and are clustered by firm. ${ }^{* * *},{ }^{* *},{ }^{*}$ denote significance at the $1 \%, 5 \%$, and $10 \%$ levels, respectively.

\begin{tabular}{|c|c|c|c|}
\hline & OLS & Probit & Logit \\
\hline Local Seniors & $\begin{array}{r}-4.6 \\
(13.6)\end{array}$ & $\begin{array}{r}-0.61 \\
(1.85)\end{array}$ & $\begin{array}{r}-1.5 \\
(3.9)\end{array}$ \\
\hline Net Income & $\begin{array}{l}-61.8^{* * *} \\
(17.2)\end{array}$ & $\begin{array}{l}-3.2^{* * *} \\
(1.2)\end{array}$ & $\begin{array}{l}-8.2^{* *} \\
(3.3)\end{array}$ \\
\hline Cash & $\begin{array}{r}0.8 \\
(3.2)\end{array}$ & $\begin{array}{r}0.07 \\
(0.46)\end{array}$ & $\begin{array}{r}0.0 \\
(1.0)\end{array}$ \\
\hline Q & $\begin{array}{l}2.7^{* * *} \\
(0.5)\end{array}$ & $\begin{array}{l}0.23^{* * *} \\
(0.03)\end{array}$ & $\begin{array}{l}0.44^{* * *} \\
(0.08)\end{array}$ \\
\hline Debt & $\begin{array}{r}-1.3 \\
(3.2)\end{array}$ & $\begin{array}{r}0.53^{*} \\
(0.30)\end{array}$ & $\begin{array}{r}0.88 \\
(0.64)\end{array}$ \\
\hline Volatility & $\begin{array}{l}119.2^{* * *} \\
(11.9)\end{array}$ & $\begin{array}{l}10.5^{\star * *} \\
(1.3)\end{array}$ & $\begin{array}{l}22.2^{* * *} \\
(2.9)\end{array}$ \\
\hline Two-Year Lagged Return & $\begin{array}{l}-2.8^{* * *} \\
(0.5)\end{array}$ & $\begin{array}{l}-0.42^{* * *} \\
(0.14)\end{array}$ & $\begin{array}{l}-1.2^{* * *} \\
(0.3)\end{array}$ \\
\hline Log of Market Value & $\begin{array}{l}-5.4^{* * *} \\
(0.9)\end{array}$ & $\begin{array}{l}-0.90^{* * *} \\
(0.10)\end{array}$ & $\begin{array}{l}-1.6^{* * *} \\
(0.2)\end{array}$ \\
\hline Log of Assets & $\begin{array}{l}3.8^{* * *} \\
(0.9)\end{array}$ & $\begin{array}{l}0.55^{* * *} \\
(0.09)\end{array}$ & $\begin{array}{l}1.0^{* * *} \\
(0.2)\end{array}$ \\
\hline Asset Growth & $\begin{array}{l}-7.5^{* * *} \\
(2.5)\end{array}$ & $\begin{array}{l}-0.80^{* * *} \\
(0.28)\end{array}$ & $\begin{array}{l}-1.6^{* * *} \\
(0.6)\end{array}$ \\
\hline $\begin{array}{l}\text { Pseudo } \mathrm{R}^{2} \\
\text { Number of Observations }\end{array}$ & $\begin{array}{l}0.240 \\
5,907\end{array}$ & $\begin{array}{l}0.505 \\
5,907\end{array}$ & $\begin{array}{l}0.516 \\
5,907\end{array}$ \\
\hline
\end{tabular}




\section{Table IA.V}

\section{Propensity of Sale and Local Seniors}

The Cox proportional hazards model employs a nonparametric estimate of the baseline hazard (i.e., the probability of selling the stock in month $t$ after the purchase, conditional on no prior sale). The first column features a common baseline hazard $\lambda_{0}(t)$, whereas the next two columns report results allowing for stock-specific baseline hazards $\lambda_{j}(t)$. The proportional hazards model (assuming a common-baseline hazard rate) takes the functional form of $\lambda_{0}(t) * \mathrm{e}^{\mathrm{X}_{i, t}{ }^{\beta}}$, where:

$$
\begin{aligned}
\mathrm{X}_{i, t} \beta= & \beta_{1}{ }^{\star} \text { GAIN }_{i, t-1}+\beta_{2}{ }^{*} \operatorname{GAIN}_{i, t-1}{ }^{*} \text { December }_{i, t}+\beta_{3}{ }^{*} \text { LOSS }_{i, t-1}+\beta_{4}{ }^{*} \text { LOSS }_{i, t-1}{ }^{*} \text { December }_{i, t}+ \\
& \beta_{5}{ }^{*} \text { December }_{i, t}+\beta_{6}{ }^{*} \text { Local }_{i}+\beta_{7}{ }^{*} \text { Senior }_{i, t}+\beta_{8}{ }^{*} \text { Local }_{i} \times \text { Senior }_{i, t}+\varepsilon_{i, t}
\end{aligned}
$$

GAIN $=\max ($ return, 0$)$ and LOSS $=\min ($ return, 0$)$, where return is defined as the capital appreciation of the stock since purchase. December is an indicator variable equal to one for December observations, and zero otherwise. Local is an indicator variable equal to one if the company headquarters are located within 250 miles of the household, and zero otherwise. Senior is an indicator variable equal to one if the investor is 65 years of age or older, and zero otherwise. All regressions are estimated over the full sample of 1,409,587 observations (i.e., potential monthly sale decisions), based on common-stock purchases made by slightly more than 30,000 households through a large discount broker over the period from 1991 to 1996. Standard errors (shown in parentheses) allow for heteroskedasticity as well as correlation across observations of the same household. ${ }^{* * *},{ }^{* *},{ }^{*}$ denote significance at the $1 \%, 5 \%$ and $10 \%$ levels,

\begin{tabular}{|c|c|c|c|}
\hline & Common Baseline & Stock-speci & Baselines \\
\hline & (1) & $(2)$ & (3) \\
\hline$\overline{\text { GAIN }}$ & $\begin{array}{c}0.09^{* * * *} \\
(0.01)\end{array}$ & $\begin{array}{c}0.09^{* * *} \\
(0.02)\end{array}$ & $\begin{array}{c}0.09^{\text {*** }} \\
(0.02)\end{array}$ \\
\hline Local $\times$ Senior $\times$ GAIN & & & $\begin{array}{r}0.04 \\
(0.10)\end{array}$ \\
\hline GAIN $x$ December & $\begin{array}{r}-0.02 \\
(0.03)\end{array}$ & $\begin{array}{l}-0.10^{\text {** }} \\
(0.05)\end{array}$ & $\begin{array}{l}-0.09^{\text {** }} \\
(0.05)\end{array}$ \\
\hline Local $x$ Senior $x$ GAIN $x$ December & & & $\begin{array}{r}-0.19 \\
(0.44)\end{array}$ \\
\hline LOSS & $\begin{array}{l}1.08^{\text {*atk }} \\
(0.04)\end{array}$ & $\begin{array}{l}1.65^{\text {*k+* }} \\
(0.05)\end{array}$ & $\begin{array}{l}1.66^{\text {*t* }} \\
(0.05)\end{array}$ \\
\hline Local $\times$ Senior $\times$ LOSS & & & $\begin{array}{r}-0.32 \\
(0.30)\end{array}$ \\
\hline LOSS $x$ December & $\begin{array}{l}-2.32^{\text {tot }} \\
(0.08)\end{array}$ & $\begin{array}{l}-2.52^{\text {tot* }} \\
(0.10)\end{array}$ & $\begin{array}{l}-2.52^{\text {tat }} \\
(0.10)\end{array}$ \\
\hline Local $x$ Senior $x$ LOSS $x$ December & & & $\begin{array}{r}-0.14 \\
(0.64)\end{array}$ \\
\hline December & $\begin{array}{c}0.14^{\text {**** }} \\
(0.02)\end{array}$ & $\begin{array}{c}0.15^{\text {**** }} \\
(0.02)\end{array}$ & $\begin{array}{l}0.15^{\text {*a** }} \\
(0.02)\end{array}$ \\
\hline Local $\times$ Senior $\times$ December & & & $\begin{array}{r}0.15 \\
(0.17)\end{array}$ \\
\hline Local (250 miles) & $\begin{array}{l}-0.14^{\text {**** }} \\
(0.01)\end{array}$ & $\begin{array}{l}-0.14^{\text {**** }} \\
(0.01)\end{array}$ & $\begin{array}{l}-0.14^{\text {*** }} \\
(0.01)\end{array}$ \\
\hline Senior $(65+)$ & $\begin{array}{l}-0.13^{\text {tot }} \\
(0.02)\end{array}$ & $\begin{array}{l}-0.05^{\text {t*k }} \\
(0.02)\end{array}$ & $\begin{array}{l}-0.05^{\text {twk }} \\
(0.02)\end{array}$ \\
\hline Local (250 miles) x Senior $(65+)$ & $\begin{array}{l}-0.11^{\text {*at }} \\
(0.04)\end{array}$ & $\begin{array}{l}-0.14^{\text {*t* }} \\
(0.04)\end{array}$ & $\begin{array}{l}-0.18^{\text {**t }} \\
(0.06)\end{array}$ \\
\hline
\end{tabular}
respectively. 
Table IA.VI

Dividend Payout and Local Seniors, Mover Regressions

This table presents results of OLS regressions that relate changes in dividend payer status to changes in Local Seniors, as well as changes in the other independent variables described in Table VI of the main article. The results are presented in five columns, corresponding to post-move horizons of one to five years, for the change regressions estimated over the full sample. The coefficients associated with the variables Change in Local Seniors and Firm Moved reported below are also reported in the second column of each of the five panels presented in Table VI of the main article. Standard errors (shown in parentheses) allow for heteroskedasticity and are clustered by firm. ${ }^{* * * *}{ }^{* *},{ }^{*}$ denote significance at the $1 \%, 5 \%$, and $10 \%$ levels, respectively.

\begin{tabular}{lccccc}
\hline & 1 Year & 2 Years & 3 Years & 4 Years & 5 Years \\
& Post-move & Post-move & Post-move & Post-move & Post-move \\
Change in Dividend payer Status & Relative to & Relative to & Relative to & Relative to & Relative to \\
& 1 Year & 1 Year & 1 Year & 1 Year & 1 Year \\
& Pre-move & Pre-move & Pre-move & Pre-move & Pre-move \\
\hline Change in Local Seniors & $98.1^{* *}$ & $163.2^{* *}$ & $187.1^{* *}$ & $213.4^{* *}$ & $300.9^{* * *}$ \\
Firm Moved & $(41.1)$ & $(69.6)$ & $(82.4)$ & $(89.1)$ & $(114.3)$ \\
& 1.0 & -0.2 & -0.7 & -0.8 & 0.8 \\
Change in Net Income & $(1.4)$ & $(1.6)$ & $(2.2)$ & $(2.6)$ & $(3.6)$ \\
Change in Cash & $-1.2^{*}$ & $-1.5^{*}$ & $-3.2^{* * *}$ & $-2.5^{* *}$ & $-2.9^{*}$ \\
Change in Q & $(0.7)$ & $(0.8)$ & $(0.9)$ & $(1.2)$ & $(1.5)$ \\
Change in Debt & 1.5 & -0.7 & -0.5 & 2.3 & 4.1 \\
Change in Volatility & $(1.7)$ & $(1.9)$ & $(2.3)$ & $(2.6)$ & $(3.0)$ \\
& $-0.37^{* * *}$ & $-0.65^{* * *}$ & $-0.91^{* * *}$ & $-1.18^{* * *}$ & $-1.16^{* * *}$ \\
Change in Two-year Lagged Return & $(0.12)$ & $(0.14)$ & $(0.17)$ & $(0.22)$ & $(0.25)$ \\
& -1.1 & $-3.7^{*}$ & $-7.8^{* * *}$ & $-6.8^{* *}$ & $-7.4^{* * *}$ \\
Change in Log of Market Value & $(1.9)$ & $(2.2)$ & $(2.7)$ & $(2.8)$ & $(2.9)$ \\
& $-21.5^{* * *}$ & $-32.6^{* * *}$ & $-44.8^{* * *}$ & $-52.9^{* * *}$ & $-58.9^{* * *}$ \\
Change in Log of Assets & $(3.0)$ & $(3.7)$ & $(4.6)$ & $(5.6)$ & $(7.1)$ \\
& $(0.20)$ & $(0.24)$ & $(0.31)$ & $(0.34)$ & $(0.39)$ \\
Change in Asset Growth & $3.5^{* * *}$ & $4.3^{* * *}$ & $5.2^{* * *}$ & $6.8^{* * *}$ & $6.8^{* * *}$ \\
Adjusted R2 & $(0.5)$ & $(0.5)$ & $(0.7)$ & $(0.8)$ & $(0.9)$ \\
Number of Observations & -1.1 & $-1.9^{* * *}$ & $-2.3^{* * *}$ & $-3.4^{* * *}$ & $-2.9^{* * *}$ \\
& $(0.7)$ & $(0.8)$ & $(0.9)$ & $(1.0)$ & $(1.1)$ \\
& -0.33 & -0.04 & 0.27 & -0.43 & -0.50 \\
& $(0.69)$ & $(0.75)$ & $(0.85)$ & $(1.02)$ & $(1.09)$ \\
& 0.024 & 0.039 & 0.055 & 0.068 & 0.070 \\
& 14,338 & 12,829 & 11,693 & 10,825 & 9,748 \\
\hline
\end{tabular}

